\title{
Güney (Denizli) Civarında Jeotermal Enerji Arama: Derin Düssey Elektrik Sondaj (DES) Ölçümlerinin Jeofizik ve Jeolojik Yorumu
}

\author{
Adil Özdemir ${ }^{1 *}, Y_{1} 1 d ı r a y ~ P a l a b ı y k^{2}$ \\ ${ }^{1}$ Adil Özdemir Danışmanlık, Ankara, Türkiye \\ ${ }^{2}$ İstanbul Teknik Üniversitesi, Maden Fakültesi, Petrol ve Doğal Gaz Mühendisliği Bölümü, İstanbul, Türkiye
}

(İlk Geliş Tarihi 1 Aralık 2019 ve Kabul Tarihi 31 Aralık 2019)

(DOI: $10.31590 /$ ejosat.653565)

\begin{abstract}
ATIF/REFERENCE: Özdemir, A. \& Palabıyık, Y. (2020). Güney (Denizli) Civarında Jeotermal Enerji Arama: Derin Düşey Elektrik Sondaj (DES) Ölçümlerinin Jeofizik ve Jeolojik Yorumu. Avrupa Bilim ve Teknoloji Dergisi, (17), 1198-1214.

$\ddot{O} \mathbf{z}$

Düşey elektrik sondaj (DES) yöntemi, jeolojik sorunların çözümünde başvurulan başlıca jeofizik yöntemler arasında yer alır. Kayaçların yatay veya düşey yöndeki elektriksel iletkenlik farklarından yararlanılarak jeolojik yapının aydınlatılması, elektrik rezistivite (özdirenç) yönteminin uygulamasındaki temel amaçtır. $\mathrm{Bu}$ yöntemde, yeraltı tabakalarının derinlikleri ve kalınlıkları özdirenç farklılıklarından faydalanılarak belirlenmeye çalışılır. Bu çalışmada, Güney (Denizli) civarında DES ölçümleri ile jeotermal enerji aranması amaçlanmıştır. $\mathrm{Bu}$ amaçla, $\mathrm{AB} / 2=1800 \mathrm{~m}$ kuramsal derinlik için ölçülen 15 adet özdirenç ölçümü, EarthImager 1D programı ile değerlendirilmiştir. $2 \mathrm{~B}$ rezistivite ve stratigrafik enine kesitler hazırlanmış ve yorumlanmıştır. Çalışma alanında, tektonizma kontrollü olarak jeotermal faaliyet varlığını gösteren düşük rezisitivite anomalileri belirlenmiş ve 3B kavramsal jeotermal model tasarlanmıştır.
\end{abstract}

Anahtar Kelimeler: jeotermal arama, rezistivite, düşey elektrik sondaj (DES), jeolojik yorum, Batı Anadolu

\section{Geothermal Energy Exploration around Güney (Denizli): Geophysical and Geological Interpretations of Deep Vertical Electrical Sounding (VES) Measurements}

\begin{abstract}
The vertical electrical sounding (VES) method is one of the main geophysical methods used in solving geological problems. The main purpose for the application of the electrical resistivity method is to illuminate the geological structure by utilizing the electrical conductivity differences of the rocks in the horizontal or vertical directions. In this method, depths and thicknesses of formation layers in the subsurface are tried to be determined by using resistivity differences. In this study, it is aimed to explore geothermal energy around Güney (Denizli) by VES measurements. For this purpose, 15 resistivity measurements, measured for $\mathrm{AB} / 2=1800 \mathrm{~m}$ theoretical depth, have been assessed by using EarthImager 1D software. 2D resistivity and stratigraphic cross-sections have been prepared and interpreted. In the study area, low-resistivity anomalies indicating the presence of geothermal activity controlled by tectonism have been determined and a 3D conceptual geothermal model has been designed.
\end{abstract}

Keywords: geothermal exploration, resistivity, vertical electrical sounding (VES), geological interpretation, Western Anatolia

\footnotetext{
* Sorumlu Yazar: Adil Özdemir, Ankara, Türkiye, ORCID: 0000-0002-3975-2846, adilozdemir2000@yahoo.com
} 


\section{Giriş}

Jeofizik etütler, özellikle faylanma ve litostratigrafik birimlerin kalınlıklarındaki değişim ve temel yapılar gibi sığ ve derin rezervuarların yapısal özelliklerini belirlemek amacıyla jeotermal aramalarda kullanılmaktadır. Jeotermal alanlarda, jeolojik birimlerin fiziksel özellikleri bulundukları ortama göre farklılıklar göstermektedir. Bu olgudan yararlanarak, jeofizik yöntemlerle jeotermal sistemlerin derinliği ve boyutları hakkında bilgilere destek sağlayıcı veriler elde edilmektedir. Bir jeotermal alanı tanımlamanın ilk koşulu, alanın jeolojik etüdüdür. Yüzeysel jeolojik çalışmalar ile bir jeotermal sistem tam olarak tanımlanamaz. Bu nedenle, ilk jeolojik çalışmalar ışığında, potansiyel jeotermal sahanın jeofizik yöntemler ile araştırılması gereklidir. Jeofizik araştırmalar, yeryüzünün görünmeyen ve bilinmeyen birimlerinin doğadaki fiziksel ilkelerden yararlanılarak incelenmesi ve fiziksel özeliklerine bağlı olarak tanımlanmasıdır. Bu bağlamda, dinamik bir ortam olan jeotermal sistemlerin, mutlaka fiziksel özelliklerindeki farklılıklardan yararlanarak incelenmesi gereklidir. Böylece, jeofizik araştırmalar yardımı ile araştırılan bir jeotermal alan, değiş̧ik fiziksel parametrelere bağlı olarak incelenerek ortama uygun model kurulabilir. Günümüzde, bilgisayar dünyası başta olmak üzere teknolojide yaşanan hızlı gelişmeler, bu tür çalışmalarda daha gerçekçi ve görsel sonuçların elde edilmesini sağlamaktadır. Tüm bunlara karşın, yine de en önemli husus, mühendislik yorumudur. Yorumlama sırasında; bölgenin öncel jeolojik, hidrojeolojik, jeokimyasal ve sondaj araştırmalarının önemli oranda katkısı olmaktadır. Jeotermal alanların jeofizik yöntemlerle araştırılması sırasında kullanılan farklı fiziksel yöntemler, söz konusu alanın değişik özelliklerinin ortaya çıkarılmasını sağlayacaktır. Bu özellikler, ortamın temel jeolojik birimlerini belirlemenin yanı sıra, ortamdaki dinamik karakterin incelenerek modellenmesi yoluyla sistemi daha ayrıntılı tanımlayabilme olanağını da sunar. Böylece, jeotermal sistemin 1sı kaynağı, rezervuar, örtü kaya, gömülü kırık sistemleri ve jeotermal akışkanı yüzeye taşıyan kırıklar ve faylar üzerindeki iletim hatları gibi önemli özellikleri tanımlanmaya çalışlarak sistemin daha gerçekçi bir modeli kurulabilir.

Düşey elektrik sondaj (DES) yöntemi, jeolojik sorunların çözümünde kullanılan başlıca jeofizik yöntemler arasında yer alır. Kayaçların yatay veya düşey yöndeki elektriksel iletkenlik farklarından yararlanılarak, jeolojik yapının aydınlatılması, elektrik özdirenç yönteminin uygulamasındaki temel amaçtır. Bu çalı̧̧ada, Schlumberger yöntemi ile alınan DES ölçümleri ile çalışma alanının yeraltı jeolojisinin ve jeotermal potansiyelinin yorumlanması amaçlanmıştır. $\mathrm{Bu}$ amaçla, $\mathrm{AB} / 2=1800 \mathrm{~m}$ kuramsal derinlik için 15 adet DES ölçüsü alınmış, alınan ölçüler EarthImager 1D programı ile değerlendirilmiştir. Bu çerçevede, DES eğrileri, özdirenç ve stratigrafik enine kesitler, hazırlanmış ve yorumlanmıştır. Bu çalışmada, belirlenen enine kesit hatları boyunca tektonizma kontrollü olarak jeotermal aktivite varlığını belirten düşük özdirenç anomalileri belirlenmiştir.

Çalışma alanında, alttan üste doğru sırasıyla, (1) Paleozoik yaşlı metamorfik kayaçlar (gözlü gnays ve şist) (2) Paleozoik yaşlı mermerler, (3) Üst Miyosen - Pliyosen yaşlı Ulubey formasyonu, (4) Pliyo-Kuvaterner yaşlı Asartepe formasyonu ve (5) Kuvaterner yaşlı alüvyonlar olmak üzere 5 farklı birim bulunmaktadır (Şekil 1). Büyük Menderes Grabeni’nde (Batı Anadolu) çok sayıda jeotermal amaçlı çalışma yapılmıştır ve Türkiye'nin en yüksek entalpili jeotermal sahaları, bu graben içerisinde yer almaktadır (Şekil 2). Türkiye'de şu ana kadar keşfedilmiş jeotermal sistemler, çoğunlukla sıvının hakim olduğu rezervuarları içermektedir. Türkiye'deki en büyük iki graben sistemi olan Büyük Menderes ve Gediz Grabenleri’nde orta-yüksek sıcaklıktaki jeotermal sahalardan üretim yapan 30'un üzerinde jeotermal enerji santrali bulunmaktadır (Haklıdır, 2017).
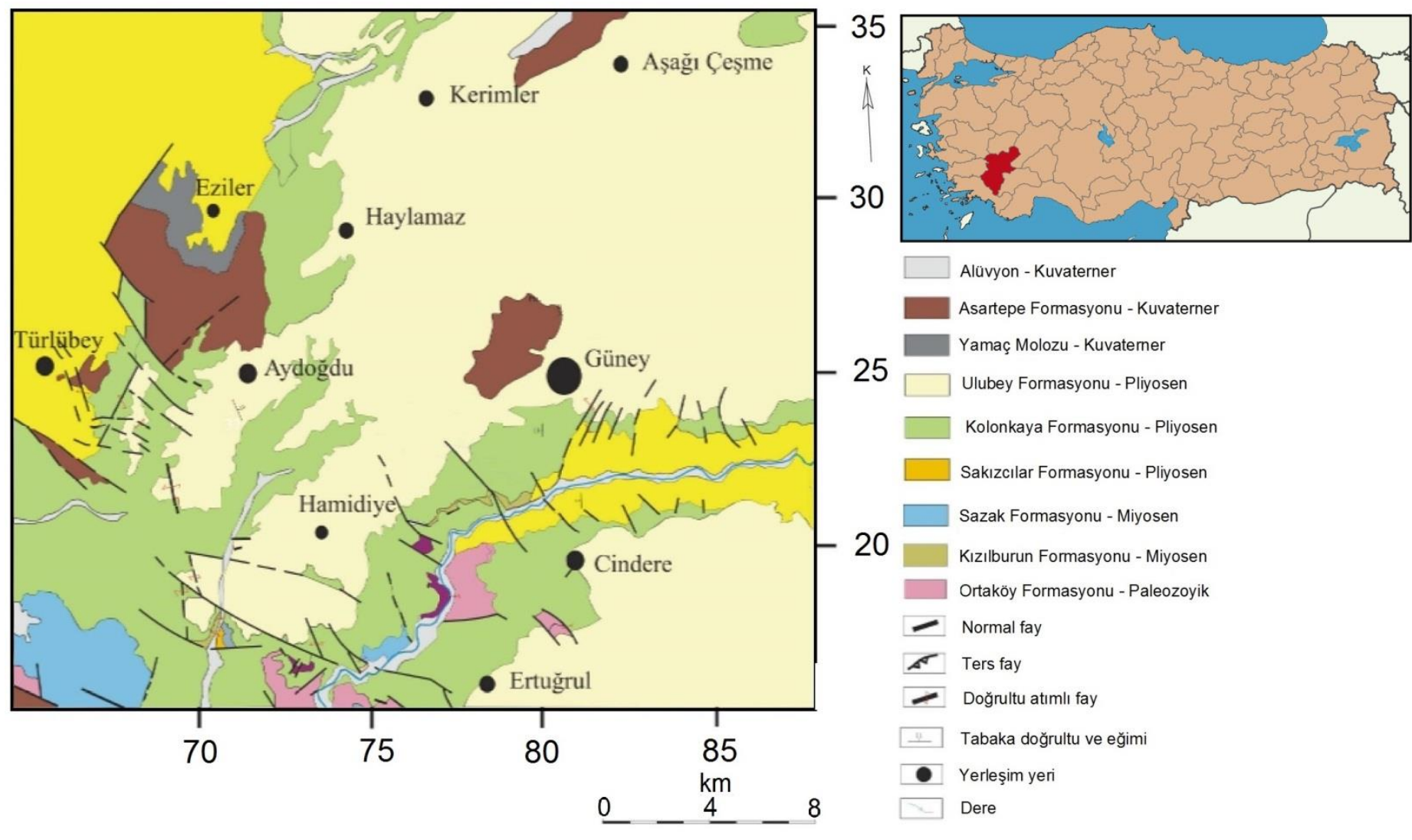

Şekil 1. Çalı̧̧ma alanının jeoloji haritası (Bülbül, 2005'den düzenlenmiştir) 

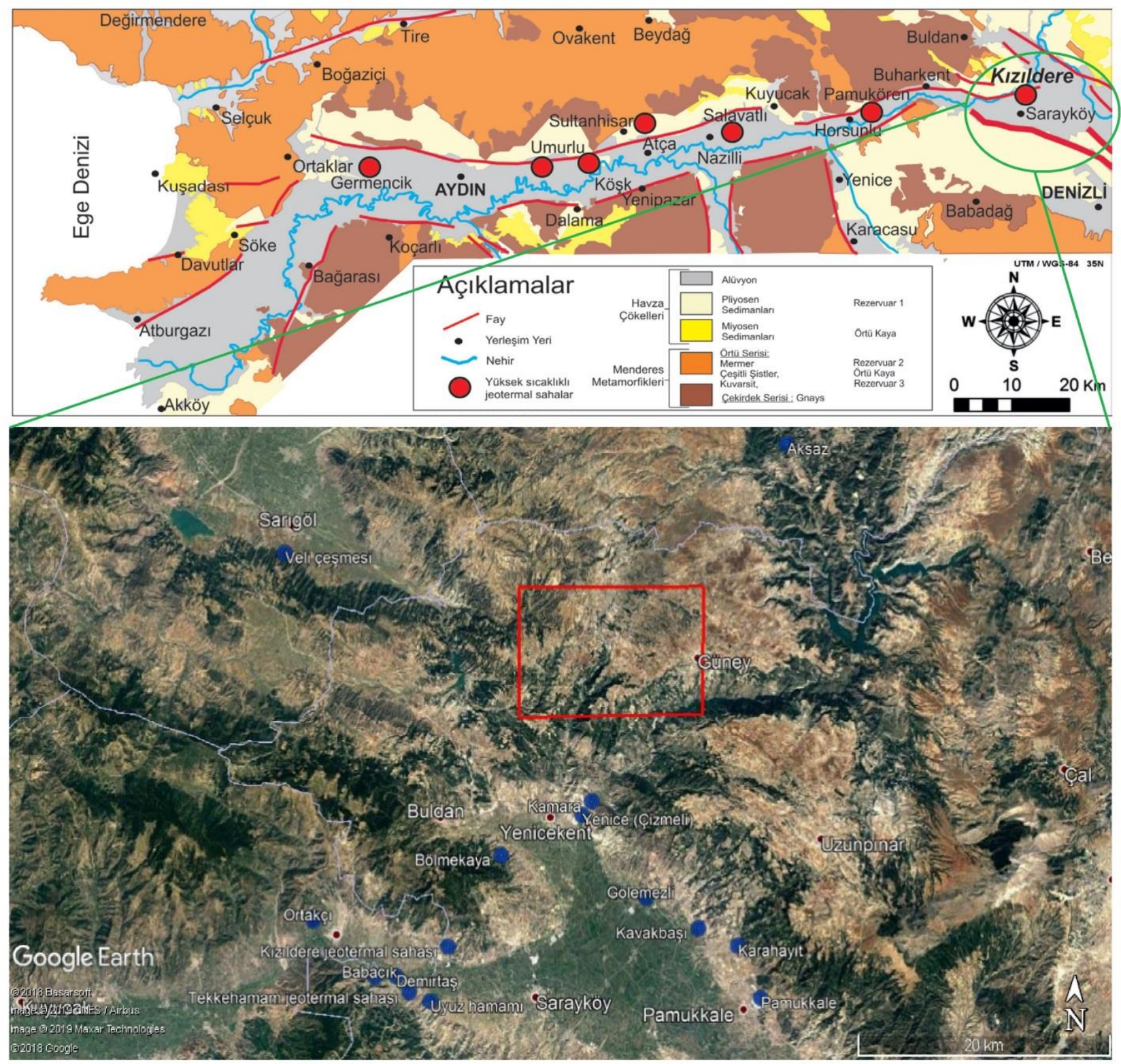

Şekil 2. Çalışma alanının bulunduğu bölgenin jeotermal potansiyeli (Haklıdır ve diğ., 2012 ve MTA, 2005'den düzenlenmiştir). Kırmızı dikdörtgen, çalıșma alanını göstermektedir.

\section{Derin Düşey Elektrik Sondaj (DES) Ölçümlerinin Jeofizik ve Jeolojik Yorumu}

Elektriği iyi ileten ortamların özdirenç değeri düşük, elektriği iletmeyen ortamların özdirenç değeri yüksektir. Bu prensipten hareketle, içerisinde su bulunan formasyonların iletkenlikleri yüksek, dolayısı ile özdirençleri düşük olacaktır. Mineral çözeltisi içeren akışkanların bulunduğu formasyonların özdirenç değerleri ise, daha da düşük olacaktır. Ortamın özdirencini etkileyen birçok etken vardır. Bunlar; jeolojik birimlerin gözenekliliğindeki değişimler, içerdiği çözeltilerin kimyasal durumları, yoğunluklarındaki farklılıklar ve 1sı değişimleri gibi etkenlerdir. Özellikle, jeotermal bir sistemin bu tür değiş̧imlerin tümünü barındırmasıyla ortamda bulunan farklı ve hızlı değişen fiziksel özelliklerin jeofizik özdirenç araştırmasının başarısını etkilediği bilinen bir gerçektir. Jeotermal bir alan üzerinde yapılan özdirenç araştırmasında, ortamın 1sı, gözeneklilik, tuzluluk ve iyonik mineral oranındaki artış doygun kayacın özdirencini azaltııı bir etkendir. Bu önemli olgu, jeotermal akışkanın belirlenmesinde etkilidir. Ayrıca, hidrotermal etkinlikler sonucu oluşmuş kil minerallerinin varlığı da ortamın özdirencinin belirlenmesinde önemli bir etkiye sahiptir. Bu etkilerin tümü, özdirencin düşmesine neden olur ve akışkan içeren jeotermal sistemlerin tümünde gözlenir. Ancak, sıvının hakim olduğu rezervuarlar yerine buharın hakim olduğu rezervuarlar üzerinde yapılan özdirenç araştırmaları, bu tür rezervuarların göreli olarak daha yüksek özdirenç değerleri verdiğini de ortaya koymuştur. Doğaldır ki, bu tür rezervuarların suya doygun bölümleri de düşük özdirençli zonlarla tanımlanabilir. Jeotermal alanlar, tektonik aktivitenin etkin olduğu ve önemli değişimler geçirmiş yerlerde bulunmaktadır. Böylece, jeolojik açıdan birçok değişik türde süreksizliğe sahiptirler. Bu özellik, gömülü rezervuarın bilinmeyen, tanımlanmamış ve boyutları düşünüldüğünde de oldukça karmaşık olan yapısı için birçok belirsizliğe neden olabilir. Ancak, ortamda sıcak tuzlu sular ve kil içeriğinin bulunduğu durumlarda, ortamlar arasındaki yüksek özdirenç zıtlığının ortaya çıkması çözümü bir ölçüde kolaylaştırıcı bir etken olmaktadır. Jeofizik literatüründe, jeotermal aramacılıkta kullanılan özdirenç yöntemleri üzerine birçok araştırma bulunmaktadır ve çok sayıda jeotermal rezervuar bu yöntem yardımıyla araştırılmıştır. 
Jeotermal alanların çoğunluğu engebeli, dağlık alanlar üzerinde veya bu alanların yakınında bulunurlar. Bu alanların geleneksel doğrusal dizilimlerle ölçülmesi, birçok sorunu da beraberinde getirdiğinden, uygun dizilimin kullanılması, bu sorunu aşmada yardımcı olabilir. Özdirenç yöntemi, gömülü hidrotermal yapının boyutlarını belirlemek ve bu yapıları jeotermal rezervuarlar ile ilişkili termal ve hidrojeolojik yapılarla ilişkilendirmek için Schlumberger veya Wenner elektrot dizilimi kullanılarak gerçekleştirilebilir. Tüm ölçümlerin tek tek değerlendirilmesi ile, 2B (iki boyutlu) olarak hazırlanan yer-elektrik kesitlerinin saha bazında 3B (üç boyutlu) olarak değerlendirilerek alanın gerçek özdirenç yapısı yorumlanabilir. Bilindiği üzere, yerkabuğunu oluşturan kayaçların fiziksel özellikleri, bulunduğu ortamlar ve jeolojik oluşumlarına göre farklılıklar göstermektedir. Kayaçların elektriksel özdirenç özellikleri de, bu manada geniş bir aralıkta değişim gösterir. Özdirenç değeri baz alınarak bir kayacın adlandırılması, her jeotermal saha için farklılık gösterir. Özdirenç eğrilerinin, bu temel kriter dikkate alınarak değerlendirilmesi gerekmektedir. Özdirenç değerlerini ve bu değerler sonucu elde edilen eğrileri, jeotermal sahalarda etkileyen tek olumsuzluk, kayacın fiziksel özellikleri değildir. Sahanın tektonik yapısı, özdirenç değerlerini açılım doğrultusundan dolayı da etkilemektedir. Genel olarak; jeotermal sahaların engebeli yapısı, istenilen açılım doğrultusunda (faya paralel) ölçüm alınabilmesine olanak tanımamaktadır. Bu durumda, değerlendirmelerin yapılma şeklinin ve diğer özdirenç yöntemlerinden nasıl yararlanılacağının bilinmesi gerekmektedir. Jeotermal sistemin açık veya kapalı bir sistem olması durumunda, jeofizik özdirenç çalışmalarının uygulanması da farklılık göstermektedir. Jeotermal sahalarda jeotermal akışkanı bünyesinde tutan kayaçlar genel olarak gözenekli ve geçirgenliği yüksek kayaçlardır. Bu kayaçlar, kireçtaşı, mermer, kuvarsit, kalkşist ve gnays gibi yüksek özdirenç gösteren kayaçlardır. Kapalı bir jeotermal sistemde, örtü kayacı temsil eden jeolojik birimler düşük özdirence sahiptir (kil, silt, kiltaşı, marn vb.).

\section{1. Çalışma Alanında Yapılan DES Çalışmaları}

Çalışma alanının büyük bir bölümü, jeofizik uygulamalara uygun düz bir topoğrafyaya sahiptir. Jeofizik ölçüm yapılan alanların güney ve güney-güneydoğu kesimleri oldukça sarp ve engebeli bir yapıdadır. Engebeli alanlarda, DES ölçümlerini istenilen derinlikte yapmak mümkün olmamıştır. Ancak, koşullar zorlanarak derin araştırmaya uygun bölgelerde 15 adet DES ölçümü alınmış ve maksimum $1800 \mathrm{~m}$ derinliğe kadar olan jeolojik yapı araştırılmıştır (Şekil 3). Jeoelektrik arazi ölçümleri, 3 amperlik rezistivite cihazı ve ekipmanı kullanılarak alınmıştır. Güç kaynağı, 220 volt ve $5.5 \mathrm{Kw}$ 'lık alternatif akım üreten benzinli jeneratördür. Alıcının duyarlılığ 1 ise, $0.01 \mathrm{mV} / \mathrm{scala}$ 'dır. Sistemde, jeneratör grubunun oluşturduğu güç kaynağından elde edilen alternatif akım (AC), önce varyak ile ayarlanmakta; daha sonra bir redresör üzerinden geçirilerek doğru akıma (DC) çevrilmektedir. Elde edilen doğru akım (DC) yeralına verilmektedir. DC çıkış voltajı maksimum 1000 volt, yeraltına verilen akım ise maksimum 2 amper civarındadır. Kullanılan akım elektrotları (C1, C2), paslanmaz çelikten yapılmış uzun çubuklar şeklindedir. Potansiyel elektrotları (P1, P2) ise, polarize olmayan bakır sülfat içerikli elektrotlardır. Kablolar, tamamen bakırlı ve iyi yalıtılmış tiptedir. Çalışma alanında yapılan jeoelektrik etüdün amacının, jeolojik birimlerin derinlere doğru değişimini incelemek olması nedeniyle, DES ölçümlerinde Schlumberger elektrot dizilimi kullanılmıştır.

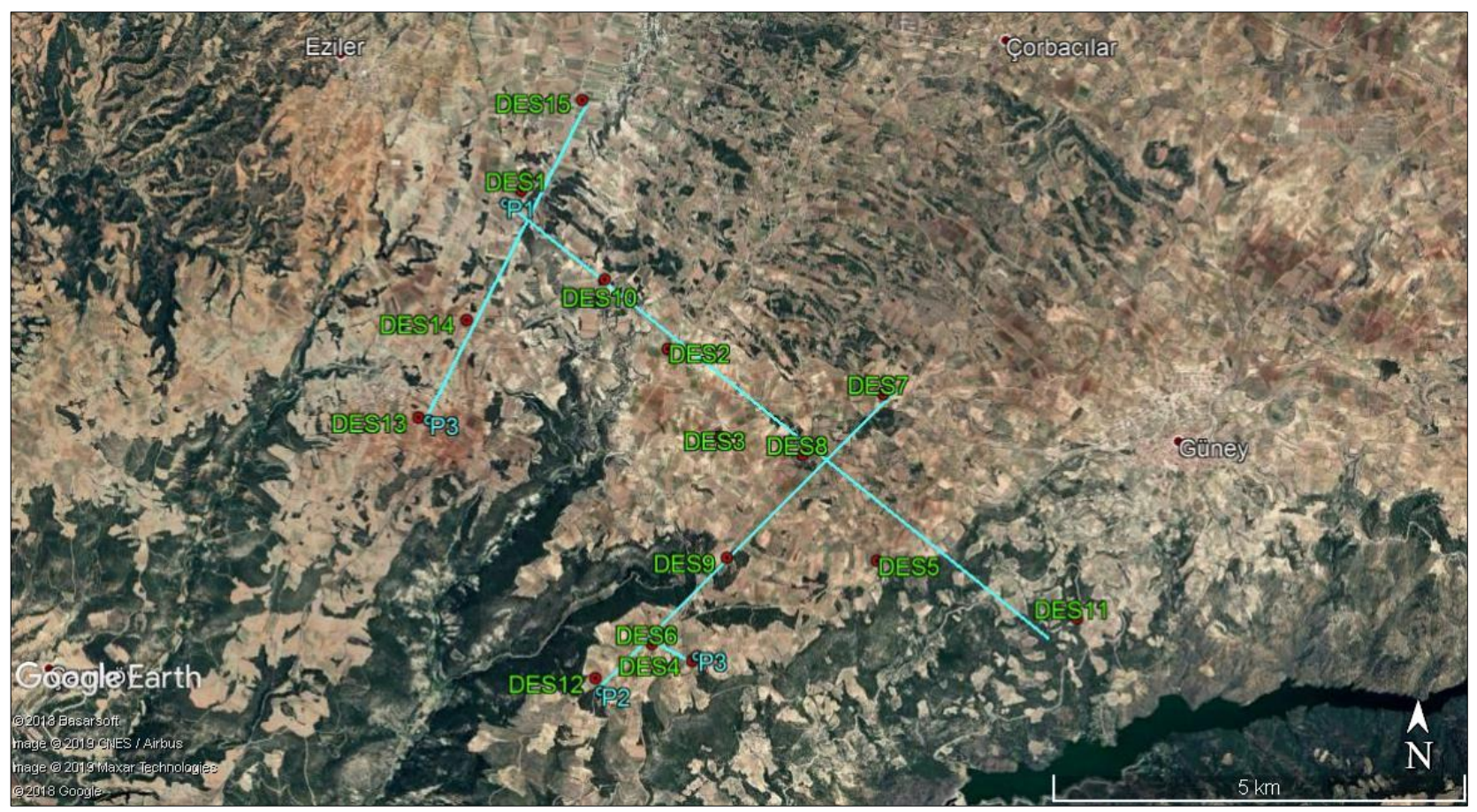

Şekil 3. Çalışma alanındaki derin düşey elektrik sondaj (DES) ölçüm noktalarının ve profillerin yer bulduru haritası

\subsubsection{DES eğrileri ve yorumları}

DES ölçümlerinin değerlendirilmesinde, bölgedeki jeolojik birimler göz önüne alınır ve yer-elektrik yapı bu birimlerle deneştirilir. $\mathrm{Bu}$ şekilde, jeolojik yapının dolaylı olarak tespitine çalışılır. Jeolojik yapı, her zaman bire bir yer-elektrik yapıya uymayabilir. Yapılan çalışmalarla elde edilen veriler, doğrudan jeotermal akışkana işaret etmez. Ancak, bu yöntem, tespit edilen yüksek özdirençli (rezistif) ve düşük özdirençli (iletken) ortamların jeolojik yapı ile deneştirilerek jeotermal sistemin tanımlanması esasına dayanır. Çalışma 
alanında yapılan DES ölçümleri sonucunda elde edilen eğriler ve değerlendirme sonuçlarından faydalanılarak, yer-elektrik yapısını daha iyi yorumlayabilmek amacıyla 4 adet profil hazırlanmışırı (Şekil 3). Tabaka özdirenç değerlerinin yatay ve düşey yönde değişimini izlemek amacıyla özdirenç seviye ve taban topoğrafyası haritaları hazırlanmıştır.

\section{P-1 Profili Görünür Özdirenç ve Yer-Elektrik Yapı Kesiti}

P-1 profili, çalışma alanının kuzey kesiminde yer alan KB-GD yönlü bir profildir (Şekil 3 ve 4). Jeoelektrik ölçülerde yüksek özdirençli temel, Paleozoyik yaşlı mermerler ve çeşitli şistler ile gnayslardan oluşan metamorfik kayaçlardır. Yüksek özdirençli temel üzerinde yer alan birim, gölsel kireçtaşları ve yer yer killi-marnlı birimlerden oluşan Neojen yaşlı Ulubey formasyonudur. Neojen yaşı kayaçlar örtü kaya niteliğindedir. Özdirenç değerleri, formasyonların genel yapısına uygun değerlerdir (Şekil 5-11).

\section{Profil 1}

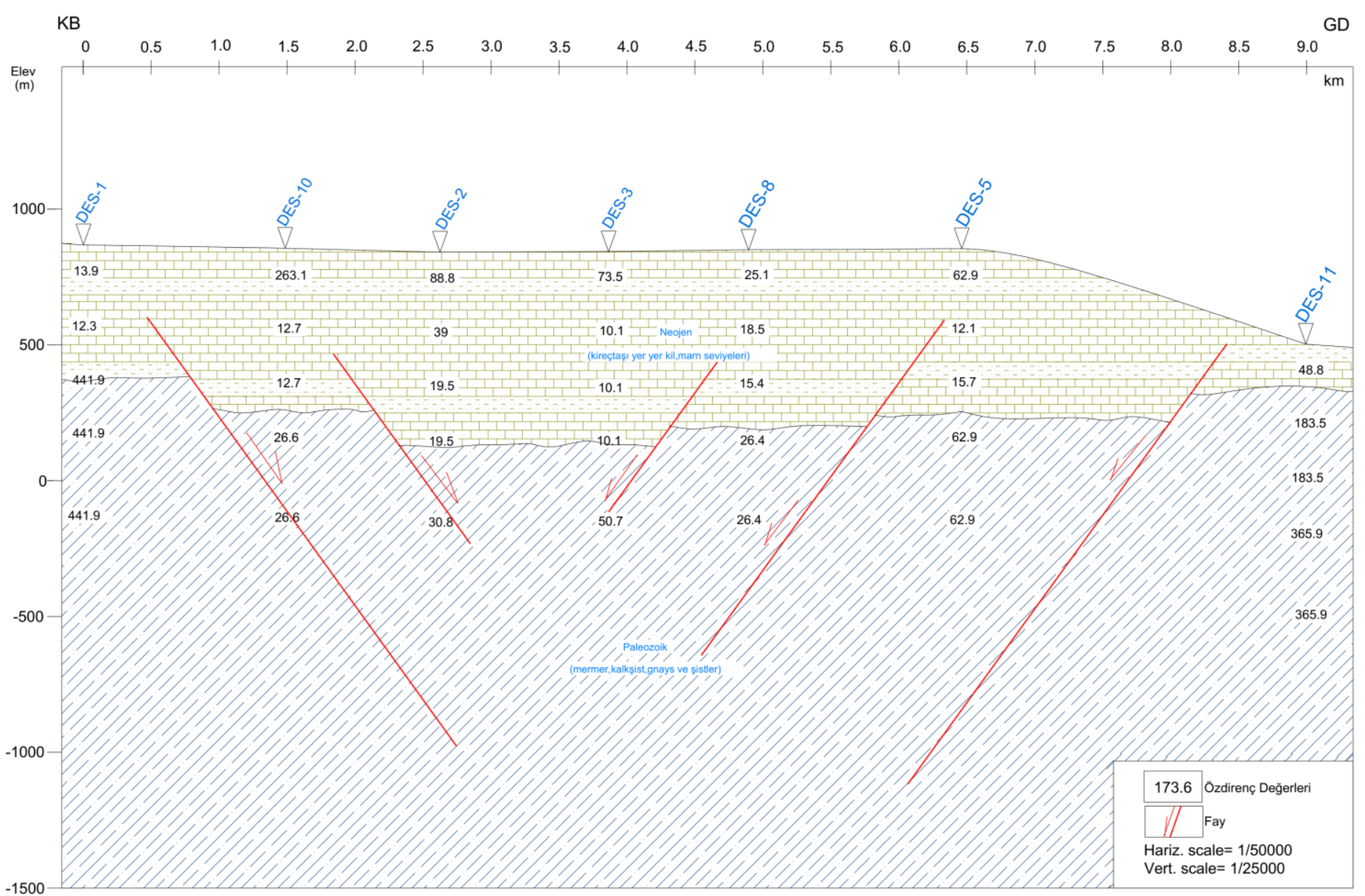

Şekil 4. P-1 profilinin yer-elektrik kesiti ve jeolojik yorumu
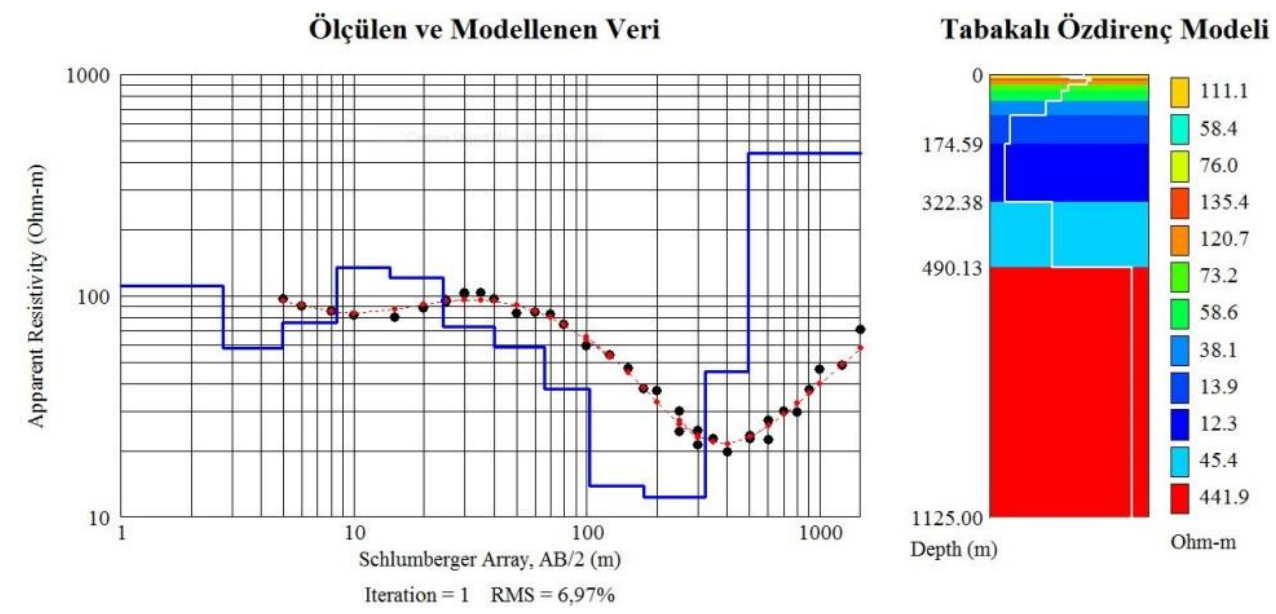

Şekil 5. DES1 noktası özdirenç ĕgrisinin değerlendirmesi. DES-1 ĕgrisinde, yüzeyden 500 m derinliğe kadar örtü kaya görülmektedir (rezistivite değeri 35 - 110 ohm.m). Bu derinlikten sonra rezistivite değerleri yükselerek mermer, şist, gnays, kuvarsit şist ve mikaşist içeren Paleozoyik yaşlı formasyon ile deneştirilen elektriki temeli göstermektedir. 

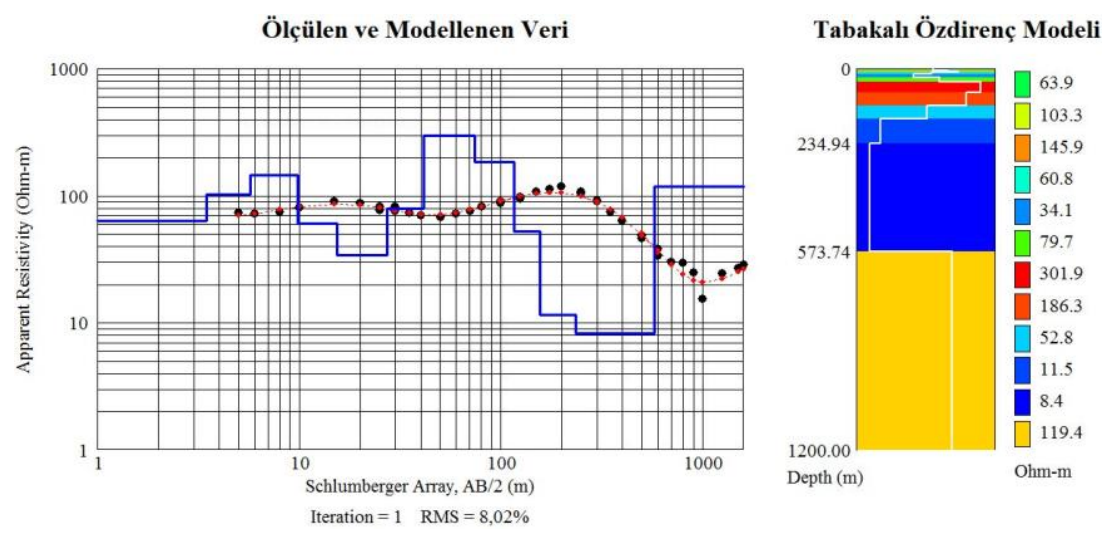

Şekil 6. DES10 noktası özdirenç eğrisinin değerlendirmesi. DES-10 ĕgrisinde, yüzeyden 600 m derinliğe kadar örtü kaya görülmektedir (rezistivite değeri 60 - 120 ohm.m). Daha sonra, 600 - $750 \mathrm{~m}$ derinlikte fay zonu görülmektedir. Bu zon aynı zamanda temel kaya - hazne kayadır (Rezistivite eğrisine göre esas temel değildir). Fay zonunun oluşturduğu ezilmeyle birlikte gelişen alterasyon nedeniyle ve jeotermal aklşkanin da etkisiyle rezistivite değeri 900 - 1100 m derinlikte tekrar düşmekte (15 - 25 ohm.m) ve 1200 m'den sonra rezistivite değerleri yükselerek mermer, şist, gnays, kuvarsit şist ve mikaşist içeren Paleozoyik yaşlı formasyon ile deneştirilen elektriki temeli göstermektedir.
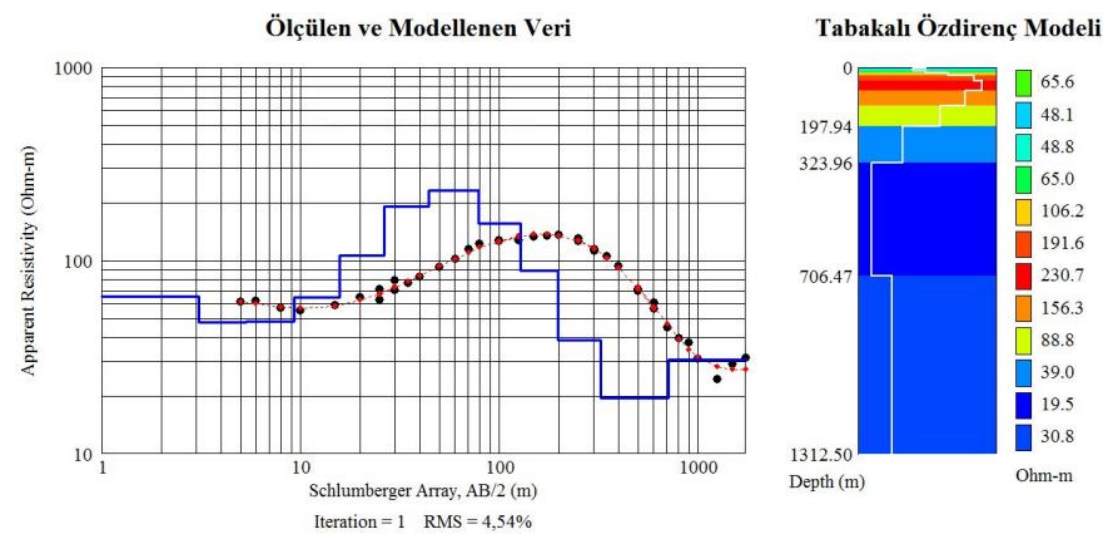

Şekil 7. DES2 noktası özdirenç ĕgrisinin değerlendirmesi. DES-2 ĕgrisinde, yüzeyden $700 \mathrm{~m}$ derinliğe kadar örtü kaya görülmektedir (rezistivite değeri 60 - 130 ohm.m). Daha sonra, 700 - 850 m derinlikte fay zonu görülmektedir. Bu zon aynı zamanda temel kaya hazne kayadır (Rezistivite ĕgrisine göre esas temel değildir). Fay zonunun oluşturduğu ezilmeyle birlikte gelişsen alterasyon nedeniyle ve jeotermal akışkanın da etkisiyle rezistivite değeri 1000 - $1200 \mathrm{~m}$ derinlikte tekrar düşmekte (25 - 30 ohm.m) ve 1250 m'den sonra rezistivite değerleri yükselerek mermer, şist, gnays, kuvarsit şist ve mikaşist içeren Paleozoyik yaşl formasyon ile deneştirilen elektriki temeli göstermektedir.
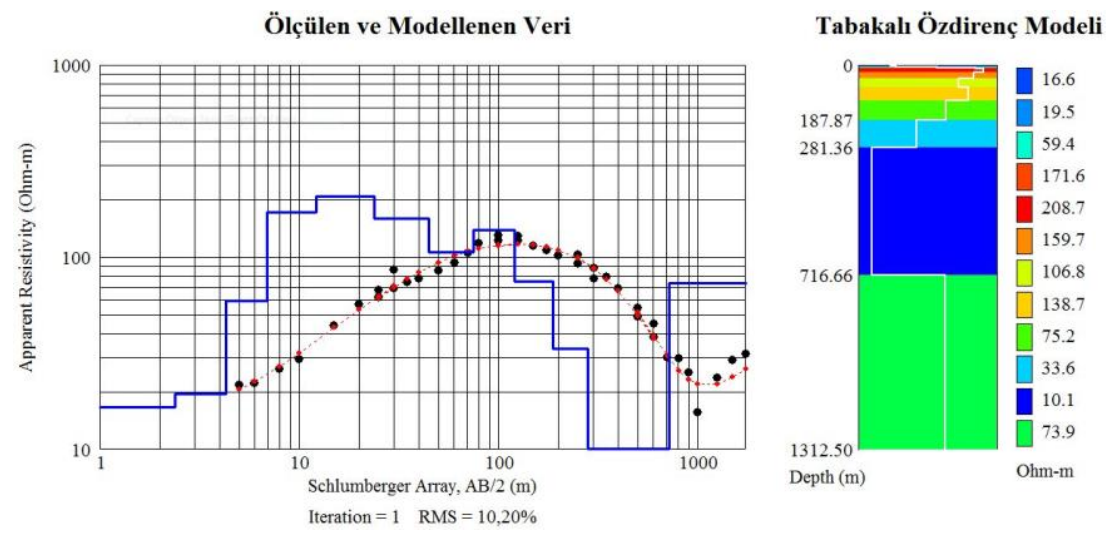

Şekil 8. DES3 noktası özdirenç eğrisinin değerlendirmesi. DES-3 ĕgrisinde, yüzeyden $700 \mathrm{~m}$ derinliğe kadar örtü kaya görülmektedir (rezistivite değeri 60 - 130 ohm.m). Daha sonra, 700 - 850 m derinlikte fay zonu görülmektedir. Bu zon aynı zamanda temel kaya hazne kayadır (Rezistivite eğrisine göre esas temel değildir). Fay zonunun oluşturduğu ezilmeyle birlikte gelișen alterasyon nedeniyle ve jeotermal akışkanin da etkisiyle rezistivite değeri 1000 - $1200 \mathrm{~m}$ derinlikte tekrar düşmekte (15 - 25 ohm.m) ve $1250 \mathrm{~m}$ 'den sonra rezistivite değerleri yükselerek mermer, şist, gnays, kuvarsit şist ve mikaşist içeren Paleozoyik yaşlı formasyon ile deneştirilen elektriki temeli göstermektedir. 
Ölçülen ve Modellenen Veri

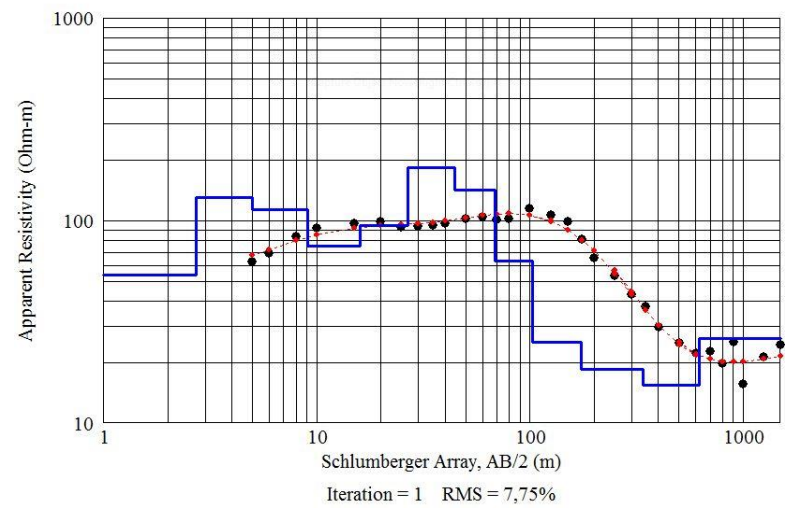

Tabakalı Özdirenç Modeli

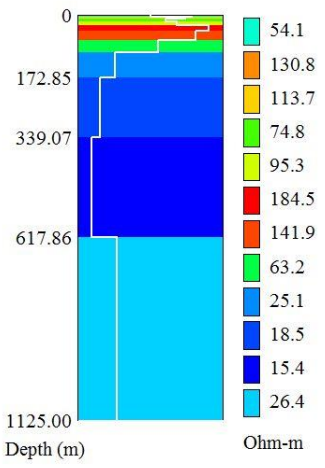

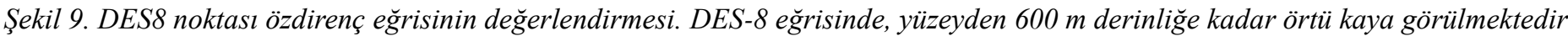
(rezistivite değeri 60 - 120 ohm.m). Daha sonra, 600 - 800 m derinlikte fay zonu görülmektedir. Bu zon aynı zamanda temel kaya hazne kayadır (Rezistivite ĕgrisine göre esas temel değildir). Fay zonunun oluşturduğu ezilmeyle birlikte gelişen alterasyon nedeniyle ve jeotermal aklşkanın da etkisiyle rezistivite değeri 800 - 1000 m derinlikte tekrar düşmekte (15 - 25 ohm.m) ve 1200 m'den sonra rezistivite değerleri yükselerek mermer, şist, gnays, kuvarsit şist ve mikaşist içeren Paleozoyik yaşl formasyon ile deneştirilen elektriki temeli göstermektedir.
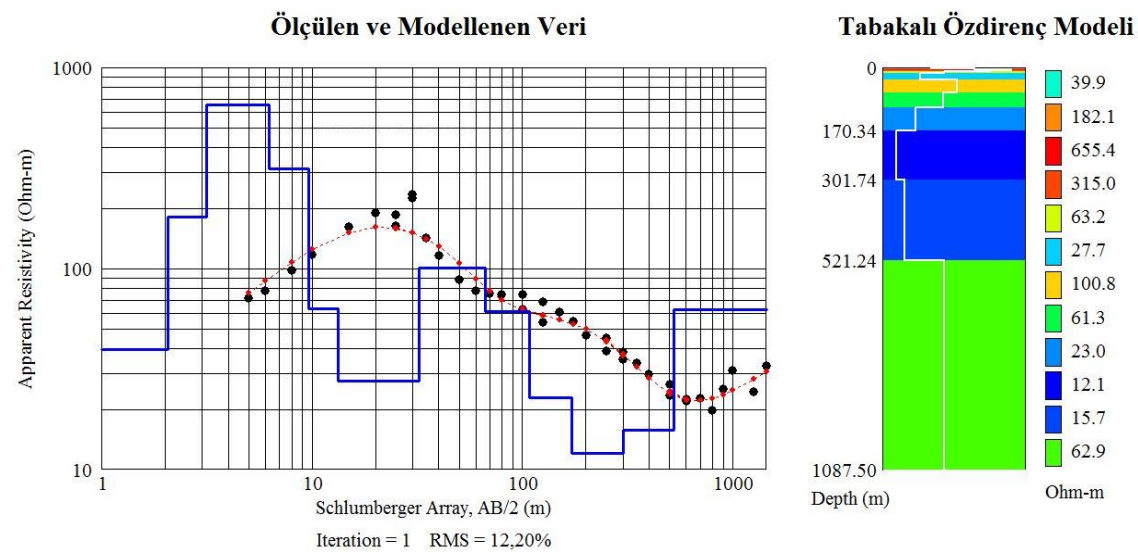

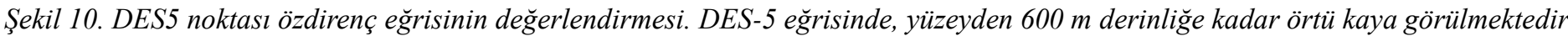
(rezistivite değeri 60 - 250 ohm.m). Daha sonra, 600 - $800 \mathrm{~m}$ derinlikte fay zonu görülmektedir. Bu zon aynı zamanda temel kaya hazne kayadır (Rezistivite ĕgrisine göre esas temel değildir). Fay zonunun oluşturduğu ezilmeyle birlikte gelişen alterasyon nedeniyle ve jeotermal aklşkanın da etkisiyle rezistivite değeri 800 - 1000 m derinlikte tekrar düşmekte (15 - 25 ohm.m) ve 1200 m'den sonra rezistivite değerleri yükselerek mermer, şist, gnays, kuvarsit şist ve mikaşist içeren Paleozoyik yaşl formasyon ile deneştirilen elektriki temeli göstermektedir.
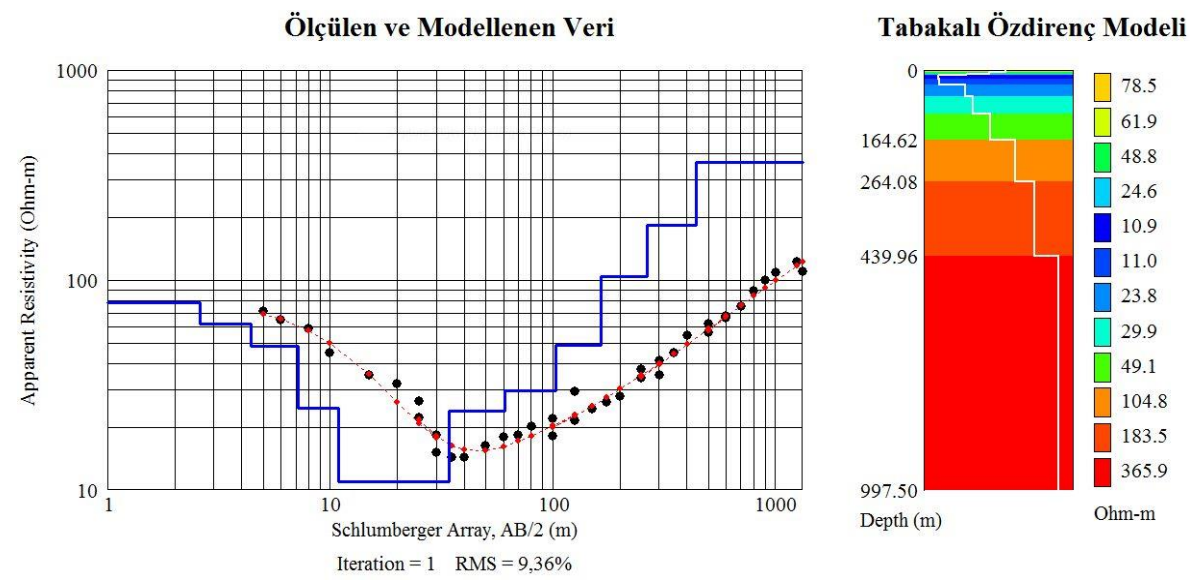

Şekil 11. DES11 noktası özdirenç ĕgrisinin değerlendirmesi. DES-11 ĕgrisinde, yüzeyden 165 m derinliğe kadar örtü kaya görülmektedir (rezistivite değeri 25 - 75 ohm.m). Bu derinlikten sonra rezistivite değerleri yükselerek mermer, şist, gnays, kuvarsit şist ve mikaşist içeren Paleozoyik yaşlı formasyon ile deneştirilen elektriki temeli göstermektedir. 
P-2 Profili Görünür Özdirenç ve Yer-elektrik Yapı Kesiti

P-2 profili, çalışma alanının kuzey kesiminde yer alan KD-GB yönlü bir profildir (Şekil 3 ve 12). Jeoelektrik ölçülerde yüksek özdirençli temel, Paleozoyik yaşlı mermerler ve çeşitli şistler ile gnayslardan oluşan metamorfik kayaçlar ile deneştirilmiştir. Yüksek özdirençli temel üzerinde yer alan birim, gölsel kireçtaşları ve yer yer killi-marnlı birimlerden oluşan Neojen yaşlı Ulubey formasyonudur. Neojen yaşlı kayaçlar örtü kaya niteliğindedir (Şekil 13-17).

Profil 2

GB

KD

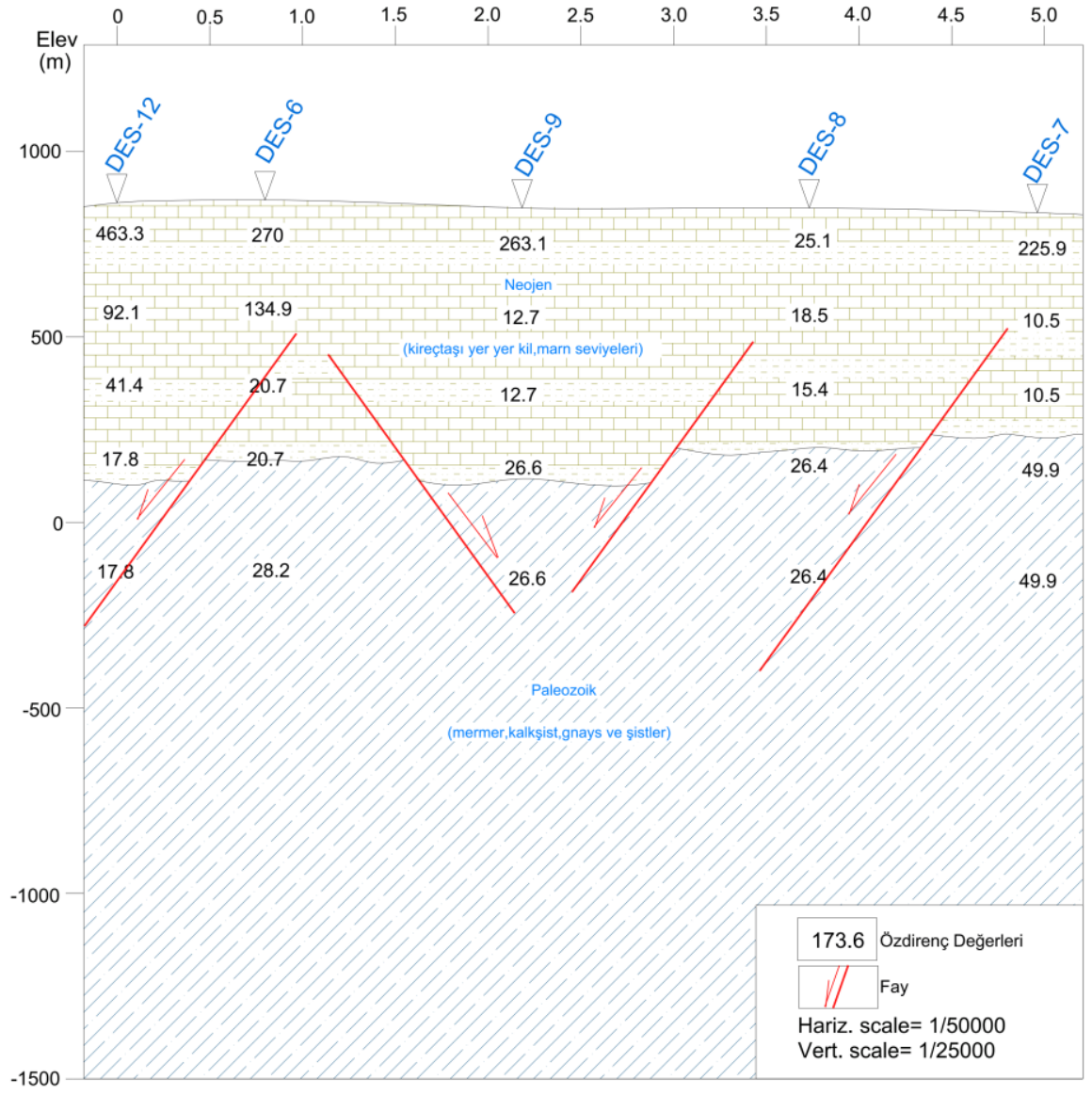

Şekil 12. P-2 profilinin yer-elektrik kesiti ve jeolojik yorumu
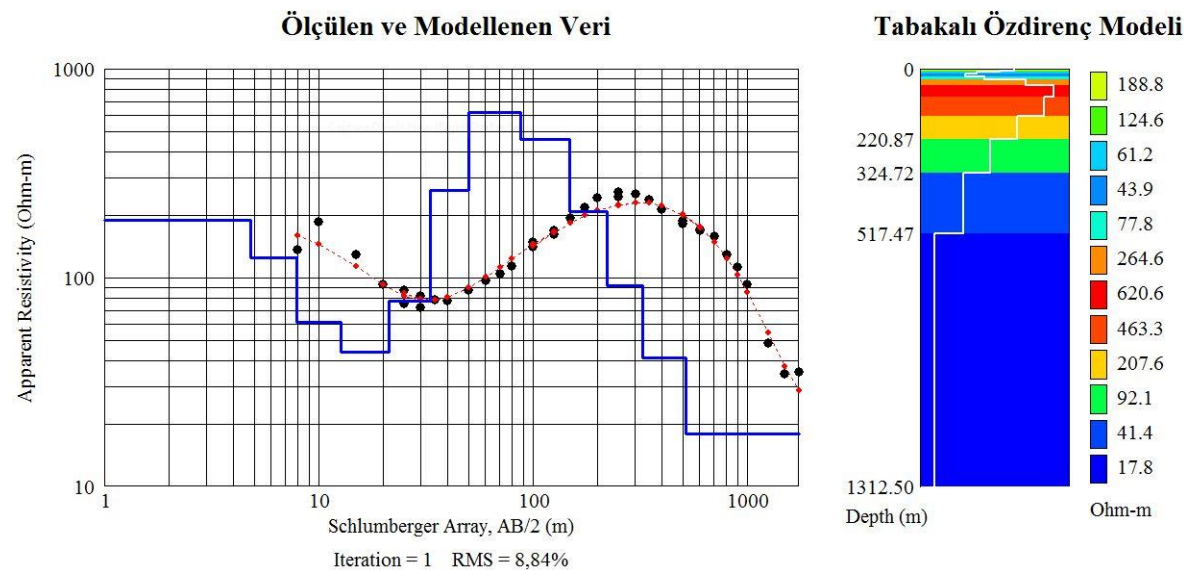

Şekil 13. DES12 noktası özdirenç ĕgrisinin değerlendirmesi. DES-12 ĕgrisinde, yüzeyden 700 m derinliğe kadar örtü kaya görülmektedir (rezistivite değeri 70 - 260 ohm.m). Daha sonra, 700 - 900 m derinlikte fay zonu görülmektedir. Bu zon aynı zamanda temel kaya - hazne kayadır (Rezistivite ĕgrisine göre esas temel değildir). Fay zonunun oluşturduğu ezilmeyle birlikte gelişen alterasyon nedeniyle ve jeotermal akışkanın da etkisiyle rezistivite değeri 1200 - 1300 m derinlikte tekrar düşmekte (35 - 49 ohm.m)'dir. Bu ölçüm, yeterli açılım alanı olmaması nedeniyle bu derinliğe kadar açılabilmiştir. 

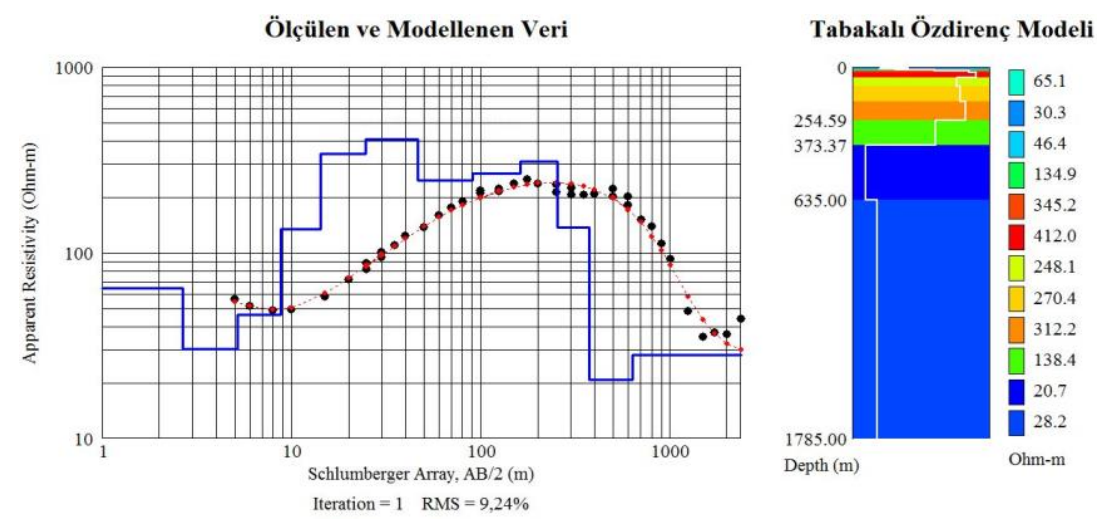

Şekil 14. DES6 noktası özdirenç ĕgrisinin değerlendirmesi. DES-6 eğrisinde, yüzeyden 700 m derinliğe kadar örtü kaya görülmektedir (rezistivite değeri 50 - 250 ohm.m). Daha sonra, 700 - 900 m derinlikte fay zonu görülmektedir. Bu zon aynı zamanda temel kaya hazne kayadır (Rezistivite eğrisine göre esas temel değildir). Fay zonunun oluşturduğu ezilmeyle birlikte gelişen alterasyon nedeniyle ve jeotermal akışkanın da etkisiyle rezistivite değeri 1250 - 1500 m derinlikte tekrar düşmekte (35 - 49 ohm.m) ve 1500 m'den sonra rezistivite değerleri yükselerek mermer, şist, gnays, kuvarsit şist ve mikaşist içeren Paleozoyik yaşll formasyon ile deneştirilen elektriki temeli göstermektedir.
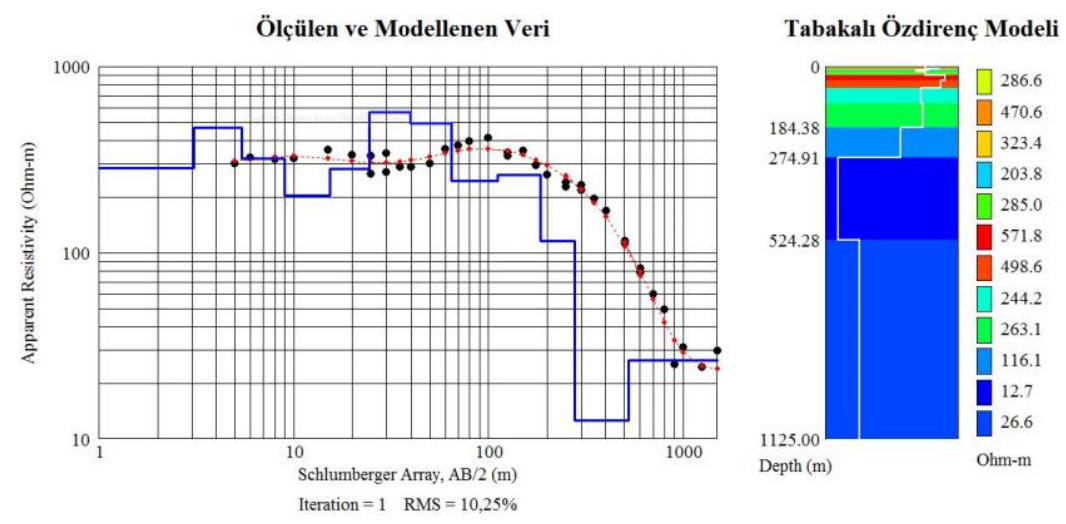

Şekil 15. DES9 noktası özdirenç ĕgrisinin dĕgerlendirmesi. DES-9 ĕgrisinde, yüzeyden 600 m derinliğe kadar örtü kaya görülmektedir (rezistivite değeri 100 - 420 ohm.m). Daha sonra, 600 - 800 m derinlikte fay zonu görülmektedir. Bu zon aynı zamanda temel kaya hazne kayadır (Rezistivite ĕgrisine göre esas temel değildir). Fay zonunun oluşturduğu ezilmeyle birlikte gelişen alterasyon nedeniyle ve jeotermal aklşkanın da etkisiyle rezistivite değeri 800 - 1000 m derinlikte tekrar düşmekte (25 - 30 ohm.m) ve 1100 m'den sonra rezistivite değerleri yükselerek mermer, şist, gnays, kuvarsit şist ve mikaşist içeren Paleozoyik yaşl formasyon ile deneştirilen elektriki temeli göstermektedir.
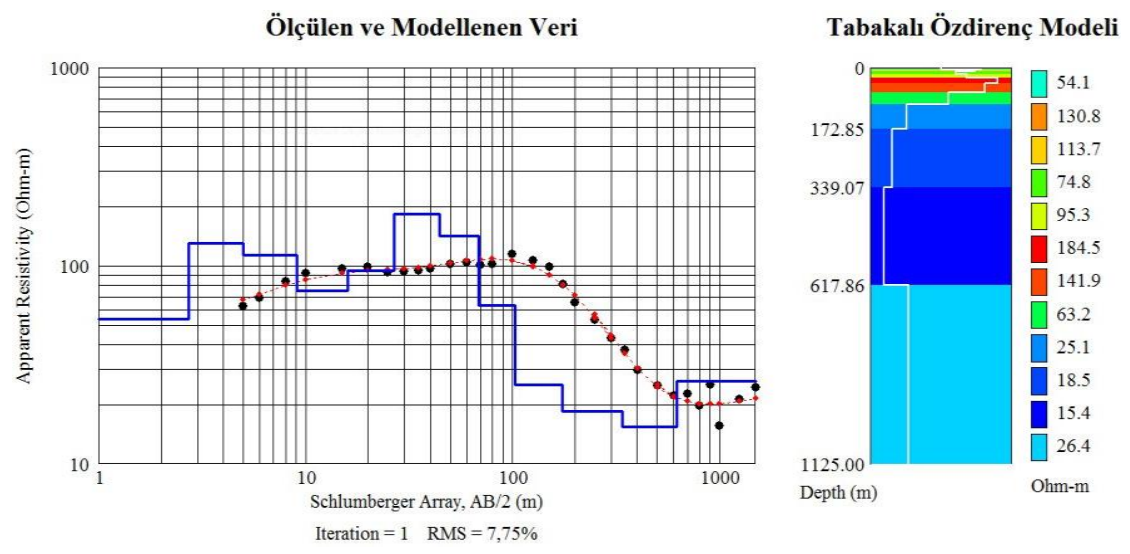

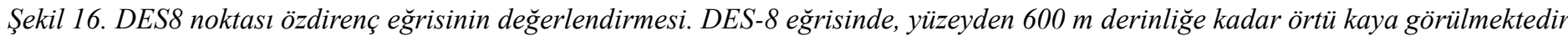
(rezistivite değeri 60 - 120 ohm.m). Daha sonra, 600 - 800 m derinlikte fay zonu görülmektedir. Bu zon aynı zamanda temel kaya hazne kayadır (Rezistivite eğrisine göre esas temel değildir). Fay zonunun oluşturduğu ezilmeyle birlikte gelişen alterasyon nedeniyle ve jeotermal aklşkanin da etkisiyle rezistivite değeri 800 - 1000 m derinlikte tekrar düşmekte (15 - 25 ohm.m) ve 1200 m'den sonra rezistivite değerleri yükselerek mermer, şist, gnays, kuvarsit şist ve mikaşist içeren Paleozoyik yaşl formasyon ile deneştirilen elektriki temeli göstermektedir. 

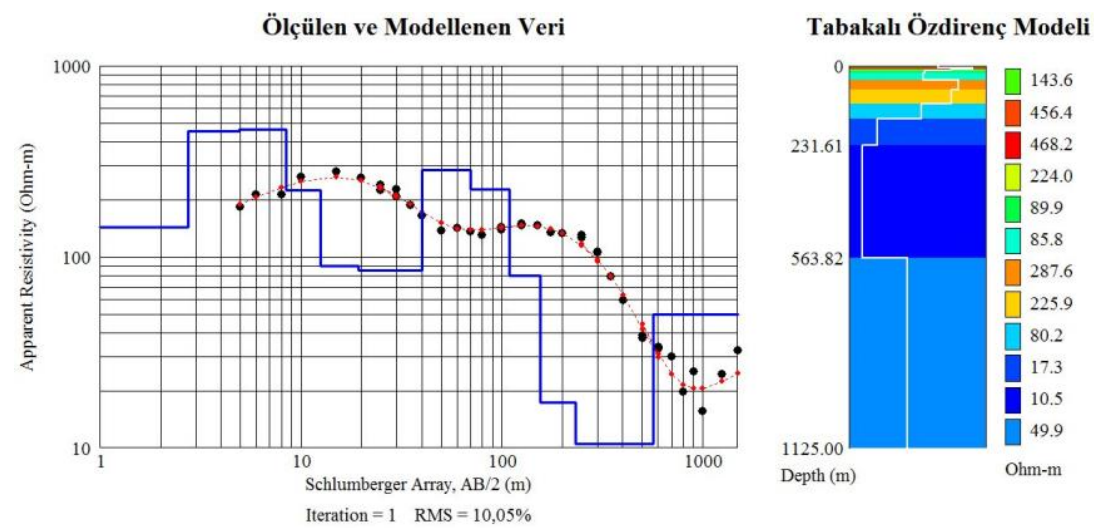

Şekil 17. DES7 noktası özdirenç ĕgrisinin değerlendirmesi. DES-7 ĕgrisinde, yüzeyden 600 m derinliğe kadar örtü kaya görülmektedir (rezistivite değeri 60 - 280 ohm.m). Daha sonra, 600 - 800 m derinlikte fay zonu görülmektedir. Bu zon aynı zamanda temel kaya hazne kayadır (Rezistivite eğrisine göre esas temel değildir). Fay zonunun oluşturduğu ezilmeyle birlikte gelişen alterasyon nedeniyle ve jeotermal aklşkanin da etkisiyle rezistivite değeri 850 - 1000 m derinlikte tekrar düşmekte (15 - 30 ohm.m) ve 1100 m'den sonra rezistivite değerleri yükselerek mermer, şist, gnays, kuvarsit şis ve mikaşist içeren Paleozoyik yaşll formasyon ile deneştirilen elektriki temeli göstermektedir.

\section{P-3 Profili Görünür Özdirenç ve Yer-elektrik Yapı Kesiti}

P-3 profili, çalışma alanının güneybatı kesiminde yer alan KB-GD yönlü bir profildir (Şekil 3 ve 18). Jeoelektrik ölçülerde yüksek özdirençli temel, Paleozoyik yaşlı mermerler ve çeşitli şistler ile gnayslardan oluşan metamorfik kayaçlar ile deneştirilmiştir. Temel birimler üzerinde yer alan birim, gölsel kireçtaşları ve yer yer killi-marnlı birimlerden oluşan Neojen yaşlı Ulubey formasyonudur. Neojen yaşlı kayaçlar örtü kaya niteliğindedir. Özdirenç düşümleri, KB-GD yönlü faylarla taşınan jeotermal akışkanın Neojen birimlerde yarattığı iletkenlik olarak yorumlanmıştır (Şekil 19 ve 20).

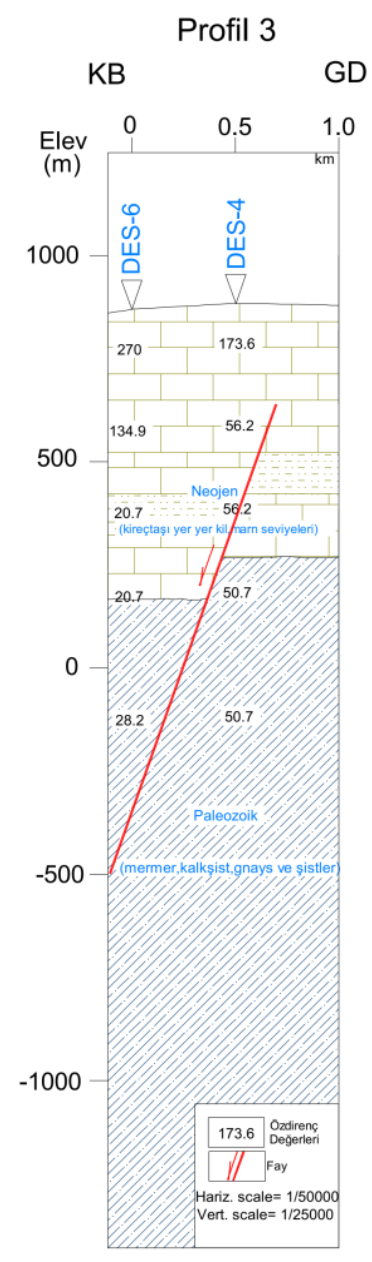

Şekil 18. P-3 profilinin yer-elektrik kesiti ve jeolojik yorumu 

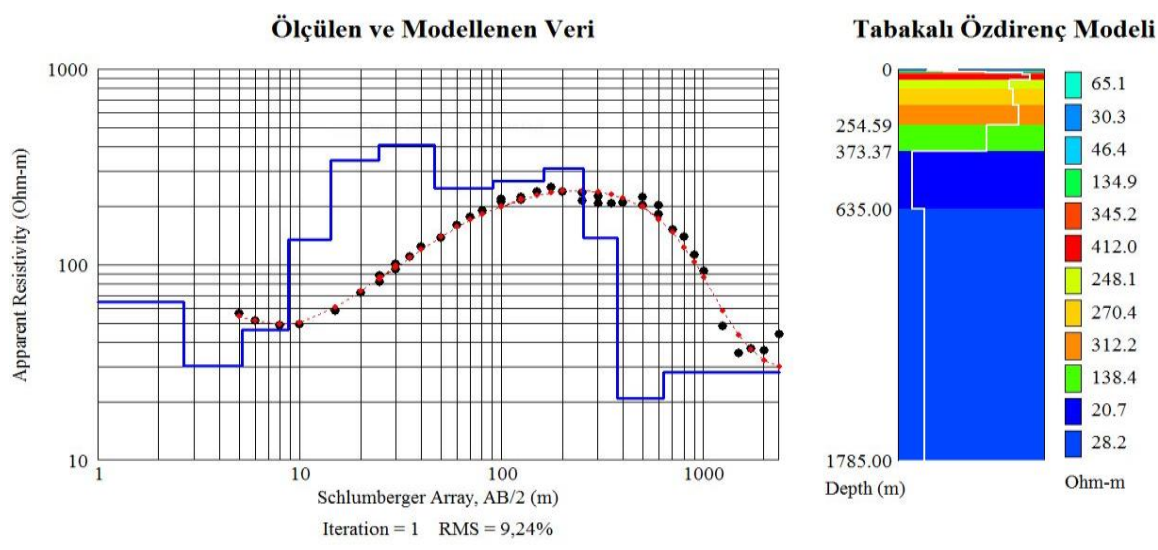

Şekil 19. DES6 noktası özdirenç eğrisi ve değerlendirme sonuçları. DES-6 eğrisinde, yüzeyden $700 \mathrm{~m}$ derinliğe kadar örtü kaya görülmektedir (rezistivite değeri 50 - 250 ohm.m). Daha sonra, 700 - 900 m derinlikte fay zonu görülmektedir. Bu zon aynı zamanda

temel kaya - hazne kayadır (Rezistivite eğrisine göre esas temel değildir). Fay zonunun oluşturduğu ezilmeyle birlikte gelişen alterasyon nedeniyle ve jeotermal aklşkanın da etkisiyle rezistivite değeri 1000 - 1500 m derinlikte tekrar düşmekte (35 - 49 ohm.m) ve 1500 m'den sonra rezistivite değerleri yükselerek mermer, şist, gnays, kuvarsit şist ve mikaşist içeren Paleozoyik yaşl formasyon ile deneştirilen elektriki temeli göstermektedir.
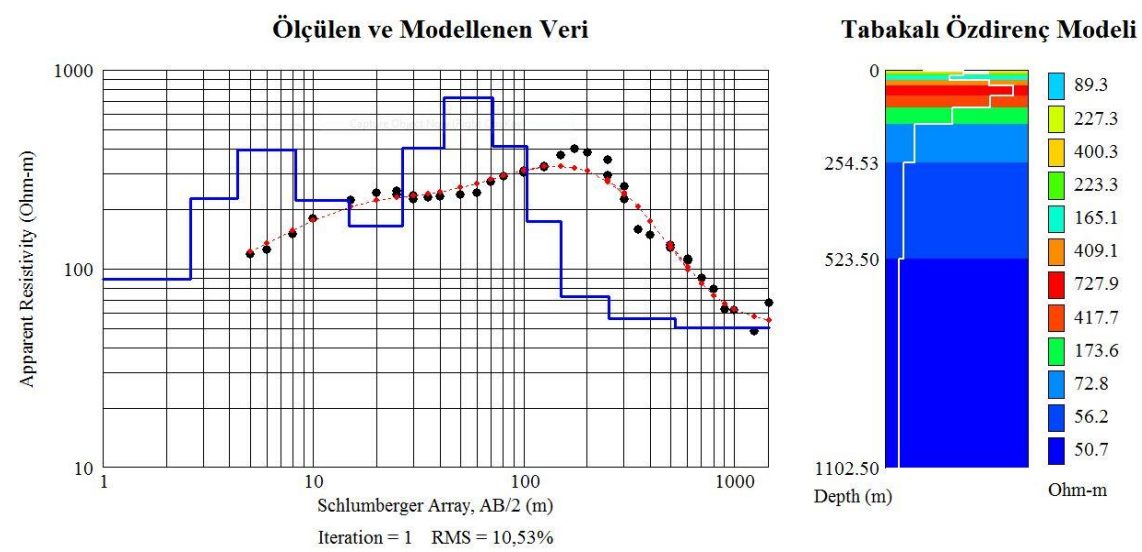

Şekil 20. DES4 noktası özdirenç ĕgrisi ve değerlendirme sonuçlart. DES-4 ĕgrisinde, yüzeyden $600 \mathrm{~m}$ derinliğe kadar örtü kaya görülmektedir (rezistivite değeri 100 - 250 ohm.m). Daha sonra, 600 - $800 \mathrm{~m}$ derinlikte fay zonu görülmektedir. Bu zon aynı zamanda

temel kaya - hazne kayadır (Rezistivite eğrisine göre esas temel değildir). Fay zonunun oluşturduğu ezilmeyle birlikte gelișen alterasyon nedeniyle ve jeotermal akışkanın da etkisiyle rezistivite değeri 800 - 1000 m derinlikte tekrar düsmekte (48 - 79 ohm.m) ve 1000 m'den sonra rezistivite değerleri yükselerek mermer, şist, gnays, kuvarsit şist ve mikaşist içeren Paleozoyik yaşlı formasyon ile deneştirilen elektriki temeli göstermektedir.

\section{P-4 Profili Görünür Özdirenç ve Yer-elektrik Yapı Kesiti}

P-4 profili, çalışma alanının kuzeybatı kesiminde yer alan KD-GB yönlü bir profildir (Şekil 3 ve 21). Jeoelektrik ölçülerde yüksek özdirençli temel, Paleozoyik yaşlı mermerler ve çeşitli şistler ile gnayslardan oluşan metamorfik kayaçlar ile deneştirilmiştir. Temel üzerinde yer alan birim, gölsel kireçtaşları ve yer yer killi-marnlı birimlerden oluşan Neojen yaşlı Ulubey formasyonudur. Neojen yaşlı kayaçlar örtü kaya niteliğindedir. Özdirenç değerleri, formasyonların genel yapısına uygun değerlerdir (Şekil 22-25). 
European Journal of Science and Technology

Profil 4

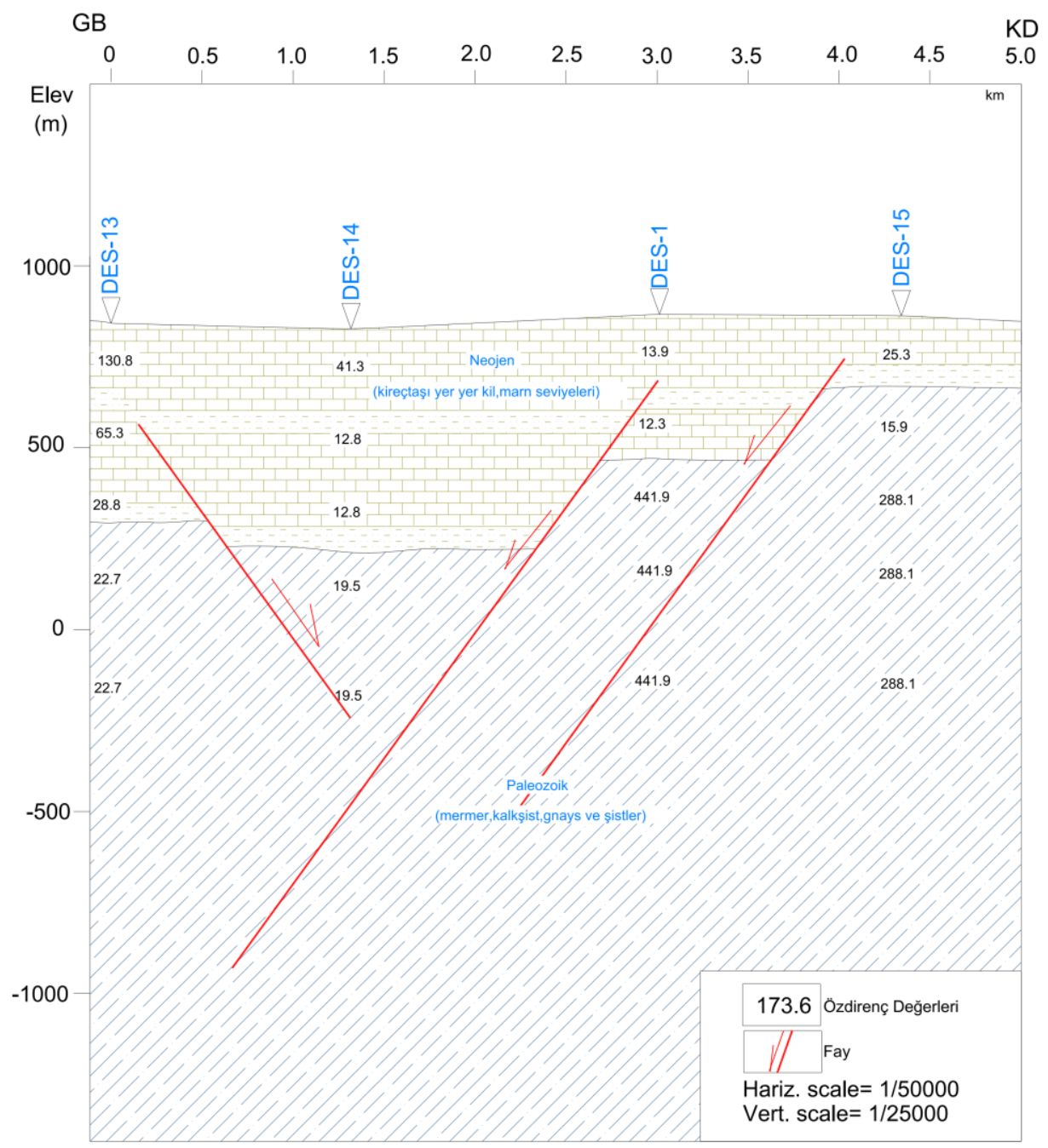

Şekil 21. P-4 profilinin yer-elektrik kesiti ve jeolojik yorumu
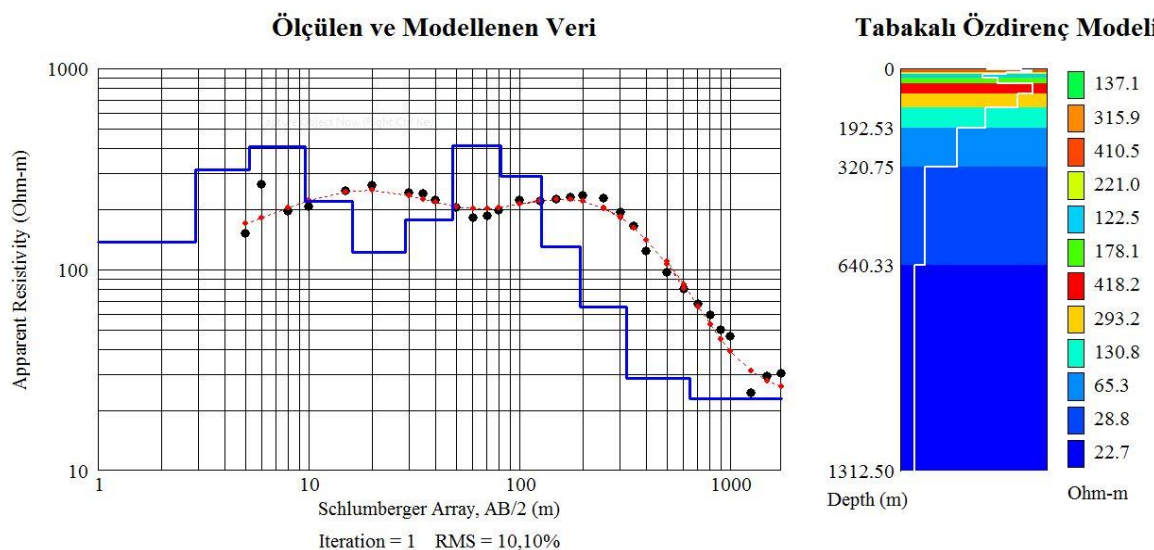

Şekil 22. DES13 noktası özdirenç ĕgrisinin değerlendirmesi. DES-13 ĕgrisinde, yüzeyden 700 m derinliğe kadar örtü kaya görülmektedir (rezistivite değeri 79 - 235 ohm.m). Daha sonra, 700 - 900 m derinlikte fay zonu görülmektedir. Bu zon aynı zamanda temel kaya - hazne kayadır (Rezistivite ĕgrisine göre esas temel değildir). Fay zonunun oluşturduğu ezilmeyle birlikte gelişen alterasyon nedeniyle ve jeotermal akışkanın da etkisiyle rezistivite değeri 1000 - $1200 \mathrm{~m}$ derinlikte tekrar düşmekte (25 - 30 ohm.m) ve 1200 m'den sonra rezistivite değerleri yükselerek mermer, şist, gnays, kuvarsit şist ve mikaşist içeren Paleozoyik yaşlı formasyon ile deneştirilen elektriki temeli göstermektedir. 

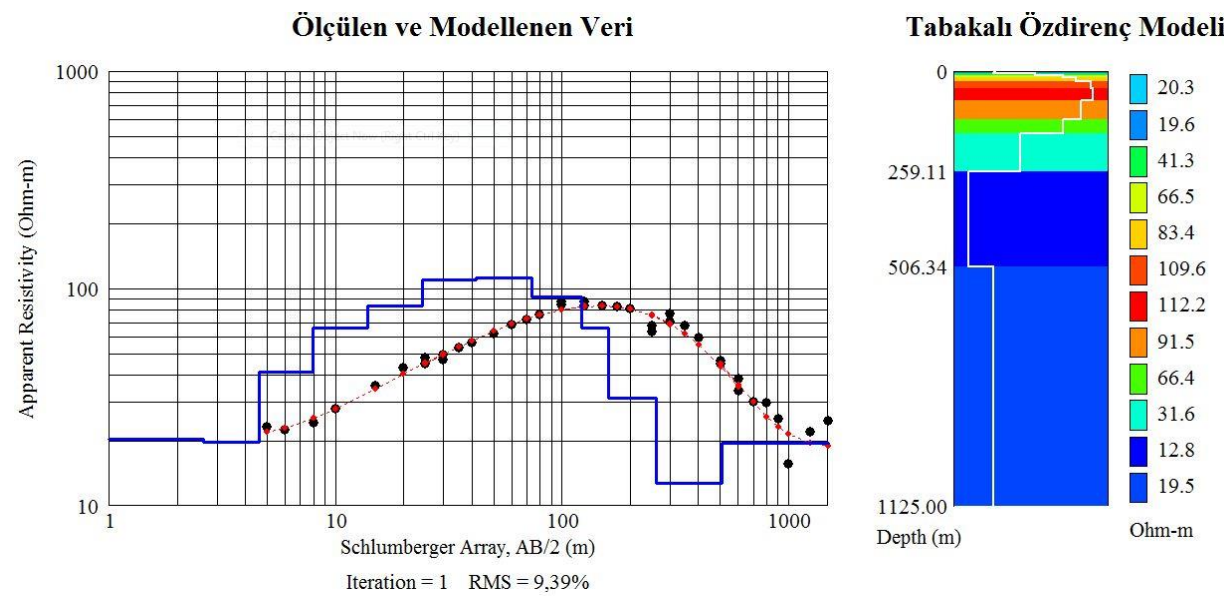

Şekil 23. DES14 noktası özdirenç eğrisinin değerlendirmesi. DES-14 ĕgrisinde, yüzeyden $700 \mathrm{~m}$ derinliğe kadar örtü kaya görülmektedir (rezistivite değeri 24 - 88 ohm.m). Daha sonra, 700 - $850 \mathrm{~m}$ derinlikte fay zonu görülmektedir. Bu zon aynı zamanda

temel kaya - hazne kayadır (Rezistivite eğrisine göre esas temel değildir). Fay zonunun oluşturduğu ezilmeyle birlikte gelişen alterasyon nedeniyle ve jeotermal akışkanın da etkisiyle rezistivite değeri 900 - 1050 m derinlikte tekrar düşmekte (15 - 25 ohm.m) ve 1100 m'den sonra rezistivite değerleri yükselerek mermer, şist, gnays, kuvarsit şist ve mikaşist içeren Paleozoyik yaşll formasyon ile deneştirilen elektriki temeli göstermektedir.
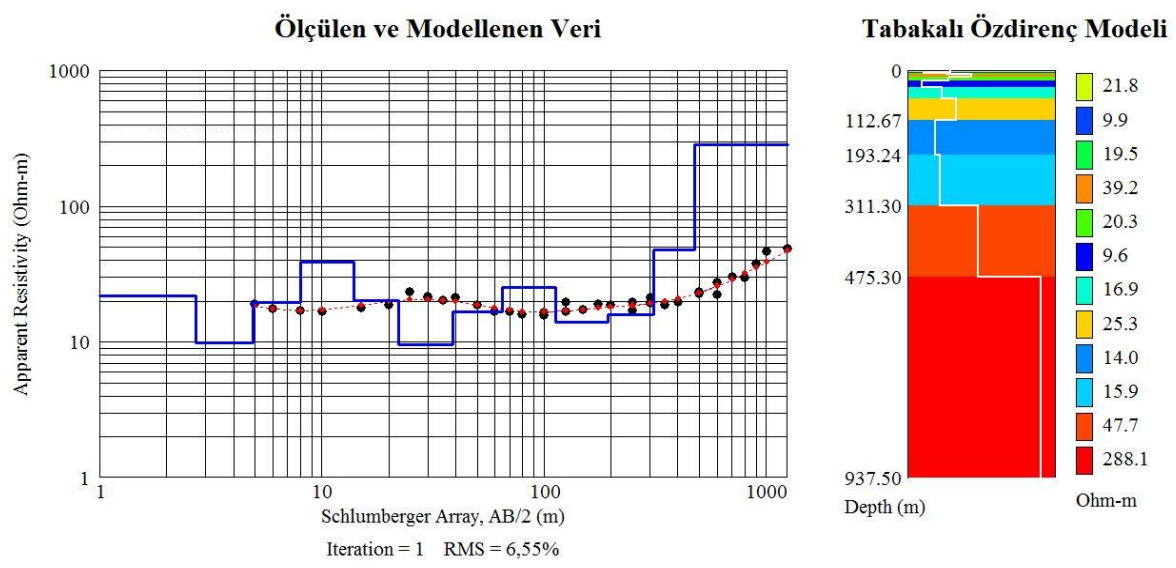

Şekil 24. DES15 noktası özdirenç ĕgrisinin değerlendirmesi. DES-15 ĕgrisinde, yüzeyden 300 m derinliğe kadar örtü kaya görülmektedir (rezistivite değeri 15 - 20 ohm.m). Bu derinlikten sonra rezistivite değerleri yükselerek mermer, şist, gnays, kuvarsit șist ve mikaşist içeren Paleozoyik yaşl formasyon ile deneştirilen elektriki temeli göstermektedir.

\subsubsection{Görünür özdirenç seviye ve taban topoğrafyası haritaları}

Seviye haritaları, jeotermal akışkan yayılımının derinlikle olan ilişkisinin açıklanması anlamında önem arz eder. Seviye ve taban topoğrafya haritalarındaki uyum, sondaj yerinin tespitinde hatanın minimize edilmesi anlamını taşı. Faya bağlı olarak oluşan özdirenç düşümleri, akışkandan kaynaklanır. Seviye haritalarının özdirenç dağılımının derinlikle değişimini göstermesi nedeniyle, çalışma alanı için 6 seviyedeki özdirenç dağılım haritaları hazırlanmıştır. Hazırlanan özdirenç seviye haritaları, DES ölçümlerinin değerlendirilmesi ile bulunan yer-elektrik katmanların özdirenç değerlerinin 100,300, 500, 700, 1000 ve $1250 \mathrm{~m}$ derinliklerdeki dağılımlarını göstermektedir. Seviye haritalarındaki 700 ve $1000 \mathrm{~m}$ seviyelerindeki görünür özdirenç dağılımı, taban topoğrafya haritası ile uyumludur. Miyosen-Pliyosen yaşlı birimlerin özdirenç değerlerinin temel birimlerden daha düşük olması gerekir. Çalışma alanı, KD’ya doğru derinleşmesine rağmen özdirenç düşümü G-GB yönünde yoğunlaşmaktadır. Bu etki, faylanmalara bağlı jeotermal aktiviteden kaynaklanabilir. Jeotermal akışkan, sıcaklığı ve mineralli yapısı nedeniyle bulunduğu ortamın özdirencini düşürücü bir özelliğe sahiptir. Çalışma alanında Neojen örtünün kalınlı̆̆ı, 165 ile $710 \mathrm{~m}$ arasındadır. Seviye haritalarında görülen özdirenç düşümleri, faylanma ve olası jeotermal etkinin özdirenç değerlerine yansıması olarak yorumlanmıştır. Özdirenç seviye haritalarında, bu seviyelerin 100, 300, 500, 700, 1000 ve $1250 \mathrm{~m}$ derinliklerdeki yayılımları izlenerek çalı̧̧ma alanındaki jeotermal sistemin yanal ve düşey yöndeki takibi yapılmıştır. $100 \mathrm{~m}$ seviyesinde, özdirenç değerleri 20 - $500 \mathrm{ohm} . \mathrm{m}$ arasında değişmektedir. Bu seviyelerde tamamen Neojen örtü bulunmaktadır. Rezistivite değerindeki düşümler, faylar ve soğuk yeraltı suyundan kaynaklanmaktadır (Şekil 25). 


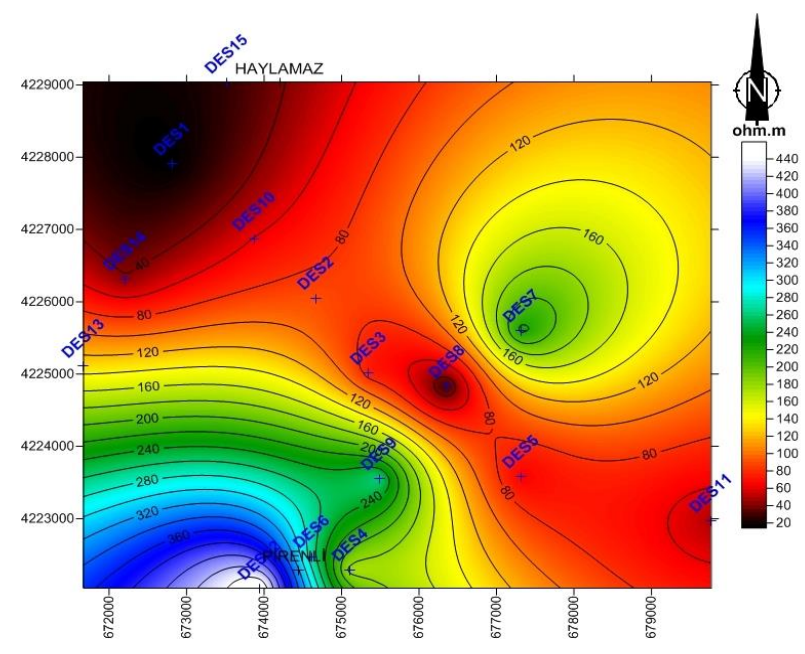

Şekil 25. AB/2 = 100 m özdirenç seviye haritasl

300 m seviyesinde, özdirenç değerleri 10 - 180 ohm.m arasında değişmektedir. Bu seviyedeki özdirenç değerleri Neojen örtü birimlerini ifade etmektedir. Sadece, DES-11 noktasında bu seviyelerde Palezoyik yaşlı temel birime girildiği görülmektedir (Şekil 26).

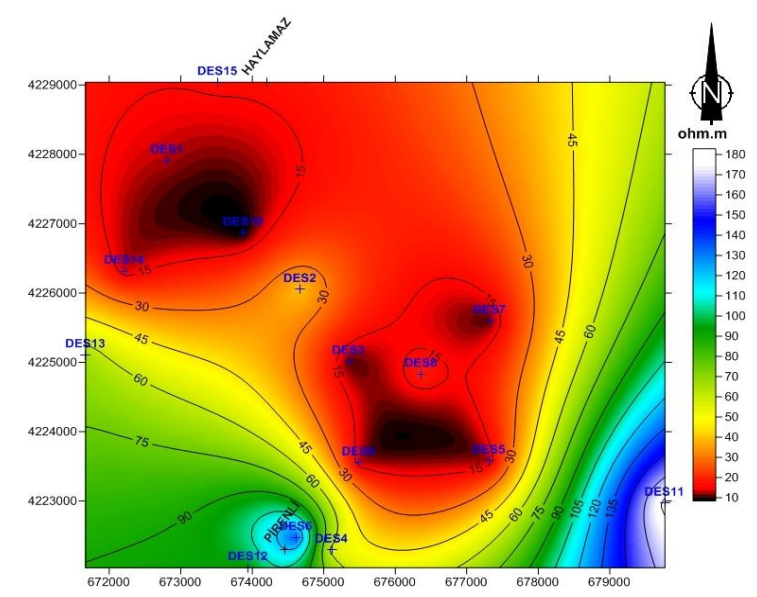

Şekil 26. AB/2 = $300 \mathrm{~m}$ özdirenç seviye haritası

500 - 700 m seviyelerinde, özdirenç değerleri 10 - 420 ohm.m arasında değişmektedir. Bu seviyedeki özdirenç değerleri Neojen örtü birimlerini ifade etmektedir. Sadece, DES-1 ve DES-11 noktalarındaki bu seviyelerde Palezoyik yaşlı temel birime girildiği görülmektedir. Eş özdirenç eğrileri, KD-GB yönelimlidir. Eğri sıklaşmalarının görüldüğü bölgeler, aynı yönlü tektonik hatlar ve bu hatların arasında kalan bölge de bir çukurlaşma yapısı görünümündedir (Şekil 27 ve 28).

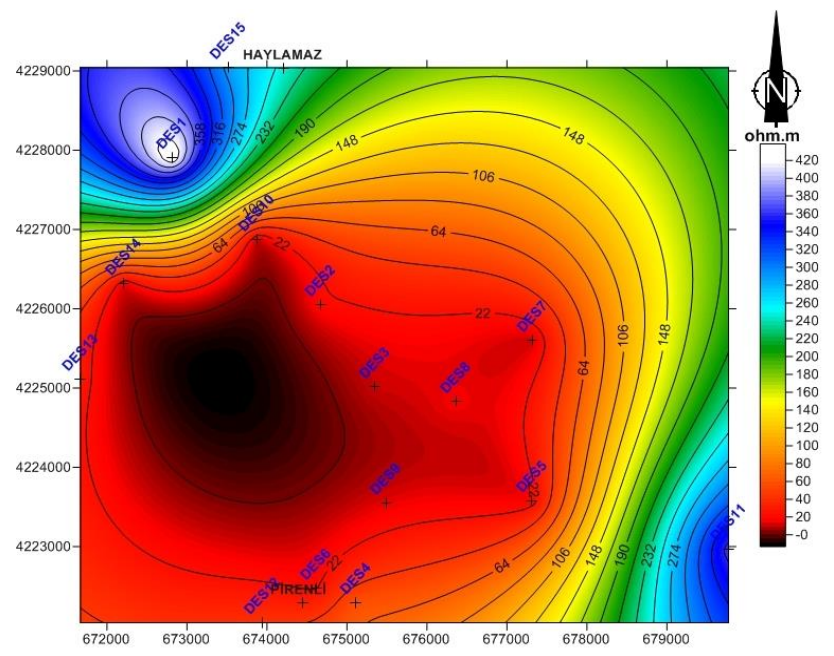

Şekil 27. AB/2 = $500 \mathrm{~m}$ özdirenç seviye haritasl 


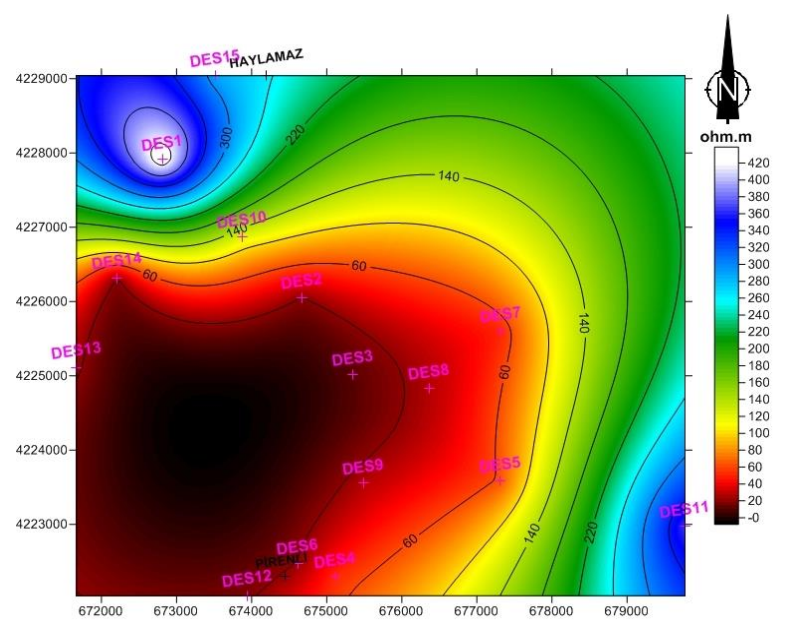

Şekil 28. AB/2 = $700 \mathrm{~m}$ özdirenç seviye haritast

1000 m seviyesinde, özdirençler 20-440 ohm.m arasında değişmektedir. Bu seviyedeki özdirenç değerlerindeki düşüşler, fay zonundan ve jeotermal akışkan etkisinden kaynaklanmaktadır. Eş özdirenç eğrileri, KB-GD yönelimlidir. Eğri sıklaşmalarının görüldüğü bölgeler, aynı yönlü tektonik hatları ifade etmektedir. Özdirenç değerlerinin, tektonizmanın ve jeotermal akışkanın etkisiyle GB yönünde düştüğü görülmektedir (Şekil 29).

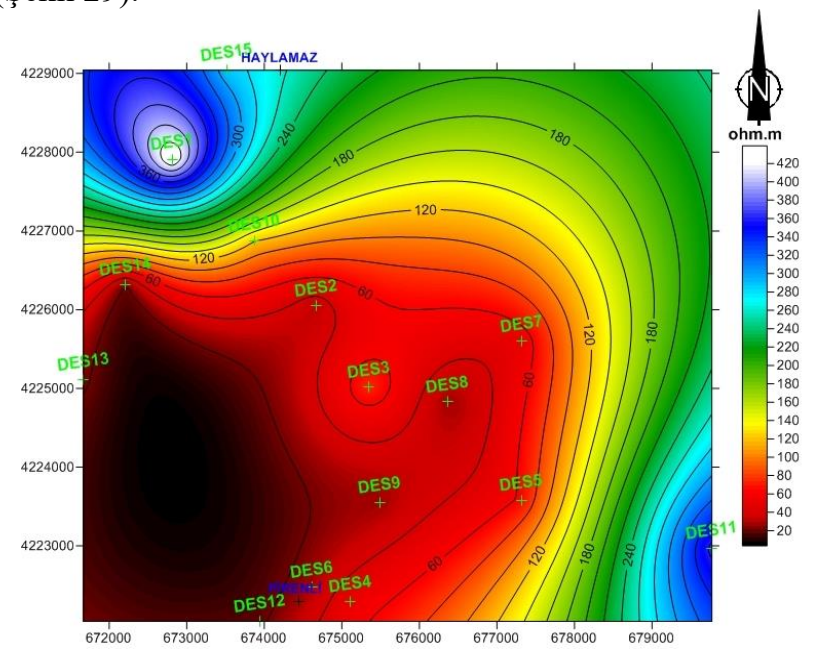

Şekil 29. AB/2 $=1000 \mathrm{~m}$ özdirenç seviye haritası

1250 m seviyelerinde, özdirençler 20-70 ohm.m arasında değişmektedir. DES13 ile DES6 noktaları arasında görülen KB-GD yönlü eş özdirenç eğrileri, aynı yönlü tektonik hatları ifade etmektedir. DES12 noktasına doğru (GB yönünde) özdirençler giderek daha düşük değerler almaktadır. Bu durum, mevcut tektonizmanın getirdiği jeotermal etki olarak yorumlanmıştır (Şekil 30).

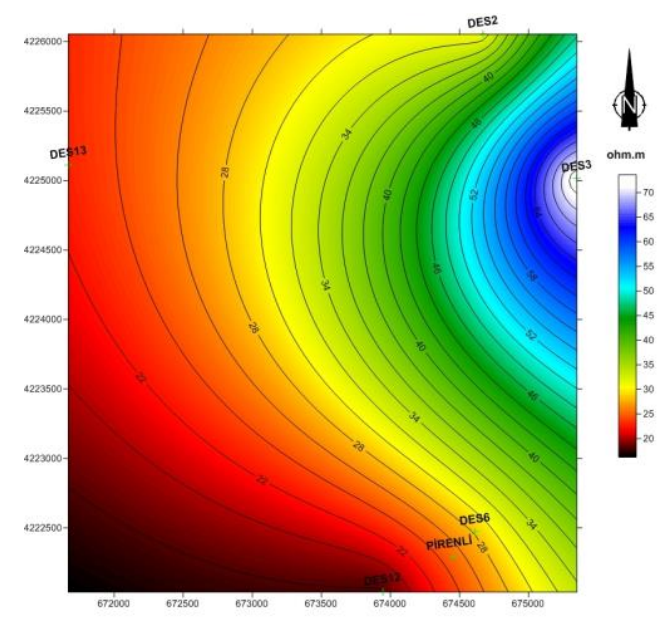

Şekil 30. AB/2 = $1250 \mathrm{~m}$ özdirenç seviye haritası 
Taban topoğrafyası haritaları, DES eğrilerinden hesaplanan rezervuar kayaca giriş derinliği ile DES eğrisinin elde edildiği noktanın kotu arasındaki fark alınarak hesaplanır. Saha genelinde, tüm noktalarda bu hesap yapılarak hesaplanan rezervuar giriş derinlikleri DES ölçü noktasına yazılır ve eş derinlik eğrileri çizilerek harita hazırlanır. Taban topoğrafyası haritalarındaki eğri sıklığı, bir fayı işaret eder. Eğrilerin uzanım doğrultuları da, fayın doğrultusunu verir. Özdirenç değerlerindeki düşümün, taban topoğrafyası haritasında tespit edilen faylarla ilişkili olması gerekir. Bunun aksi durumdaki özdirenç düşümleri kayaçların litolojik özelliklerinden kaynaklanır. Bu anlamda, taban topoğrafyası haritalarının oluşturulması, sahanın genel tektonik yapısının ortaya konulmasında vazgeçilmez bir araçtır. Çalışma alanı için hazırlanan taban topoğrafyası haritası, Paleozoyik yaşlı temel birimlerine giriş derinliğini göstermektedir. Haritadaki eğri dağılımı, KD-GB doğrultusunda uzanmaktadır. Bu durum, sahanın genel tektonik yapısını oluşturan graben faylarının doğrultusu hakkında bilgi vermektedir. Eğri sıklı̆̆ göstermektedir. Taban topoğrafyası haritası incelendiğinde, Neojen birimlerin kalınlığının KD-GB yönünde kalınlaşttğı, KB-GD yönünde azaldığı görülmektedir. Neojen birimlerin kalınlığı, KD-GB yönünde $470-710 \mathrm{~m}$, GD-KB yönünde ise $150-500 \mathrm{~m}$ civarındadır. Sahadaki bu yapının oluşumu, yaklaşık doğrultuları KD-GB ve KB-GD yönlü olan faylar ile açıklanmıştır (Şekil 31).

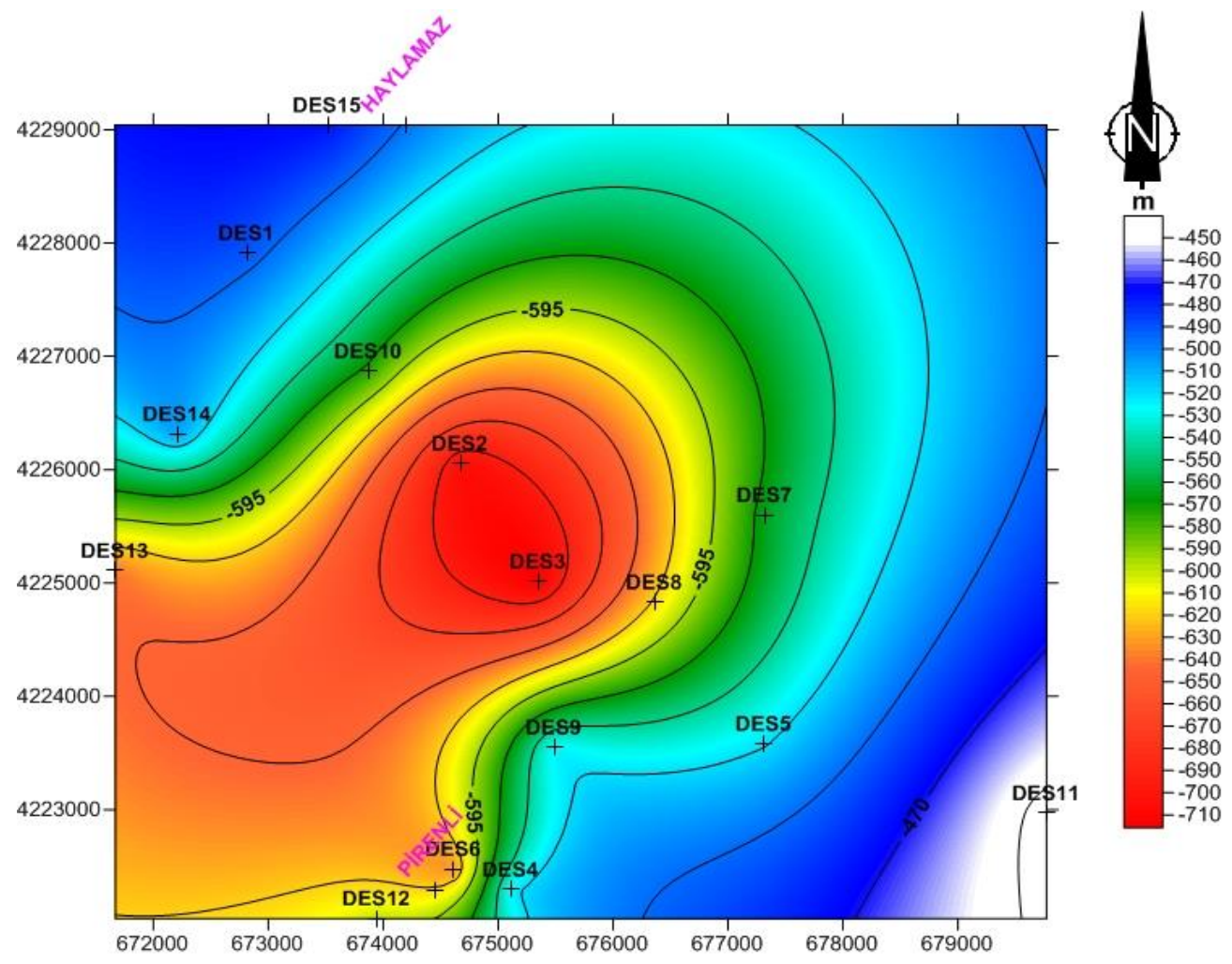

Şekil 31. Taban topoğrafyası haritası

\subsection{Kavramsal Jeotermal Model}

Çalışma alanının yakın çevresinde, birçok sıcak su kaynağı ve jeotermal sondaj kuyuları mevcuttur (Şekil 2). En yakın olan sondaj kuyuları ve sıcak su kaynakları üzerine değerlendirmeler yapılmıştı. Mevcut kaynak, kuyu verileri ve arazi gözlemleri birleştirilerek jeotermal sistem hakkında yoruma gidilmiştir. Gölemezli jeotermal alanı sondaj verilerine göre, Neojen birimin kalınlığı 600 m'dir ve kaynak ve sondajların KD-GB, KB-GD faylarının kesişme noktalarında yoğunlaşıt̆ı̆ı görülür. Gölemezli'de, 597 m derinlikteki DG-2 kuyusunun akışkan sıcaklığ $173{ }^{\circ} \mathrm{C}$ ve debisi ise 140 lt/s'dir. Aynı alanda, DG-1 kuyusunun derinliği $1500 \mathrm{~m}$ olduğu halde, akışkan sıcaklı̆̆ $188^{\circ} \mathrm{C}$, debi ise $15 \mathrm{lt} / \mathrm{s}$ 'dir. Kamara kaplıcasındaki kaynak sıcaklı̆̆ $36^{\circ} \mathrm{C}$, Yenice jeotermal alanındaki $54 \mathrm{~m}$ derinlikteki YK-1 kuyusunun akışkan sıcaklığ $157^{\circ} \mathrm{C}$ ve debisi 20 lt/s'dir. $238 \mathrm{~m}$ derinlikteki YK-2 kuyusunda akışkan sıcaklığ $67^{\circ} \mathrm{C}$ ve debisi $140 \mathrm{lt} / \mathrm{s}$ ve $250 \mathrm{~m}$ derinlikteki YK-3 kuyusunun akışkan sıcaklığ $136^{\circ} \mathrm{C}$ ve debisi $4 \mathrm{lt} / \mathrm{s}$ 'dir. Bu veriler birlikte değerlendirildiğinde, jeotermal sistemin faylar tarafından kontrol edildiği anlaşılmaktadır. Değişik yönlü fayların kesişme noktalarında jeotermal rezervuarlar daha iyi gelişmiş, faylardan uzaklaşıldıkça jeotermal rezervuarları bulmak mümkün olamamıştır. Şöyle ki, Gölemezli’deki $1500 \mathrm{~m}$ ve Kamara'daki $250 \mathrm{~m}$ derinlikteki sondajlar, fay kontrollü olmadığı için, hem sıcaklıkları hem de debileri düşüktür. Yenice'deki $54 \mathrm{~m}$ ile $238 \mathrm{~m}$ derinlikteki sondajlardan çıkan jeotermal akışkanın sıcaklıkları incelendiğinde, bölgede jeotermal gradyanın $5,5^{\circ} \mathrm{C} / 100 \mathrm{~m}$ olduğu anlaşılmaktadır.

KB-GD ve KD-GB doğrultulu fayların kontrol ettiği, Orta Miyosen öncesi yapı ile genç tektonik yapının yer yer uyumlu olduğu, sahanın güneybatısında daha genç tektoniğin etkin olduğu görülmektedir. Kamara ve Yenice bölgesinde oluşan jeotermal kaynaklar, fay sistemleri ile kontrol edilen kaynaklardır. Isı kaynağı ise, tüm Batı Anadolu için düşünüldüğü gibi kıta kabuğu içerisine sokulan magmatik kayaçlardır. Beslenme, bölgedeki yükseltileri sınırlayan faylardan meteorik beslenme şeklinde gerçekleşmektedir. Menderes Masifi'ne ait metamorfiklerin, faylanmanın etkisi ile kırıklı-çatlaklı bir yapı kazandığı bölgeler, rezervuar kaya olarak değerlendirilmiştir. Üst Miyosen-Pliyosen yaşlı çökeller örtü kayadır. Jeotermal sistem, gömülü faylar tarafindan kontrol edilmektedir (Şekil 32). 


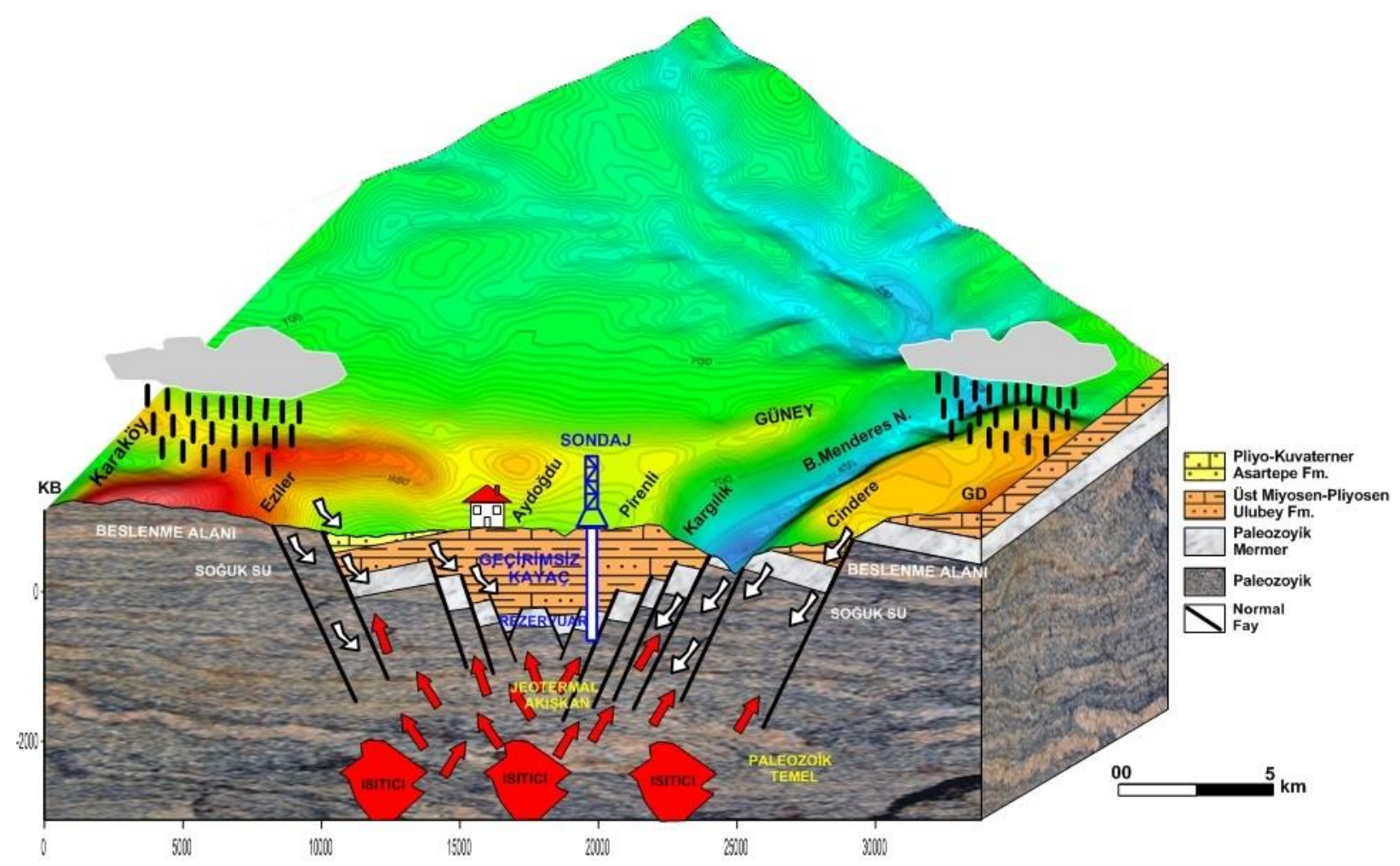

Şekil 32. Çalışma alanının kavramsal jeotermal modeli

\section{Sonuç}

DES ölçülerinde yüksek özdirençli temel, Paleozoyik yaşlı mermerler ve çeşitli şistler ile gnayslardan oluşan metamorfik kayaçlardır. Yüksek özdirençli temel üzerinde, düşük özdirençli yer alan birim, gölsel kireçtaşları ve yer yer killi-marnlı birimlerden oluşan Neojen yaşlı Ulubey formasyonudur. Neojen yaşlı kayaçlar, örtü kaya niteliğindedir. Özdirenç değerleri, formasyonların genel yapısına uygun değerlerdir. Özdirenç düşümleri, KB-GD ve KD-GB yönlü faylarla taşınan jeotermal akışkanın Neojen ve metamorfik birimlerde yarattığı iletkenlik olarak yorumlanmıştır. Seviye haritalarındaki 700 ve 1000 m seviyelerindeki görünür özdirenç dağılımı, taban topoğrafyası haritasıyla uyum içerisindedir. Miyosen-Pliyosen birimlerinin özdirenç değerlerinin temel birimlerden daha düşük olması gerekir. Çalışma alanı KD'ya doğru derinleşmesine rağmen, özdirenç düşümü çalışma alanının G-GB'sında yoğunlaşmıştır. Bu etki faylanmalara bağlı jeotermal aktiviteden kaynaklanmaktadır. Çünkü, jeotermal akışkan sıcaklığı ve mineralli yapısı nedeniyle, bulunduğu ortamın özdirencini düşürücü bir özelliğe sahiptir. Seviye haritalarında görülen özdirenç düşümleri, faylanma ve olası jeotermal etkinin özdirenç değerlerine yansıması olarak yorumlanmıştır. Buharın hakim olduğu jeotermal rezervuarlarda yapılan özdirenç araştırmaları, bu tip rezervuarların göreli olarak sıvının hakim olduğu rezervuarlara göre daha yüksek özdirenç değerleri sergilediğini ortaya koymaktadır. Sonuç olarak, çalışma alanındaki sıvının hakim olduğu sistemlere oranla göreceli olarak yüksek olan özdireç değerinin, buharın hakim olduğu bir jeotermal sistemi işaret ettiği düşünülmektedir. Taban topoğrafyası haritasında, Neojen birimlerin kalınlığının KD-GB yönlerinde kalınlaştığı, KB-GD yönünde azaldığı saptanmıştı. Neojen birimlerin kalınlı̆̆ı, KD-GB yönlerinde 470 - $710 \mathrm{~m}$, GD-KB da ise 150 - $500 \mathrm{~m}$ civarındadır. Çalışma alanında bu yapı, yaklaşık doğrultuları KD-GB ve KB-GD yönlü olan faylar varlığı ile açıklanabilir.

\section{Kaynakça}

Bülbül, M., 2005. Güney (Denizli) Dolayındaki Neojen Karbonatlarının Fasiyes İncelemesi. Dokuz Eylül Üniversitesi, Fen Bilimleri Enstitüsü Yüksek Lisans Tezi, $82 \mathrm{~s}$.

Haklıdır T.F.S., Uzun, A. and Şengün, R., 2012. Investigation of reservoir characteristics of high enthalpy geothermal fields on Büyük Menderes Graben and sulphate variations of geothermal fluids in the graben. Proceedings of International Earth Science Colloquium on the Aegean Region (IESCA), Dokuz Eylül University, İzmir, Turkey. 1-5 October 2012

Haklıdır T.F.S., 2017. Batı Anadolu'da yüksek sıcaklıklı jeotermal sistemlerde gözlenen kabuklaşma türleri ve kabuklaşma oluşumunun kontrolünün sağlanmasında kullanılan sistemler; Kızıldere-II (Denizli) jeotermal güç santrali örneği. Türkiye Jeoloji Bülteni, 60, 363-382

MTA, 2005. Türkiye Jeotermal Kaynaklar Envanteri. Envanter Serisi: 201, 849 s. 